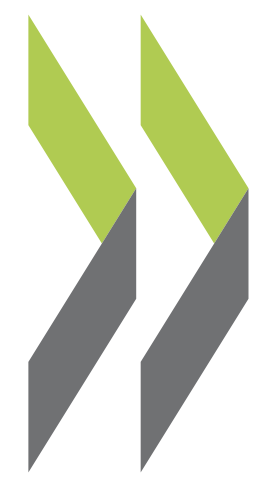

OECD Economics Department Working Papers No. 1003

Douglas Sutherland,

Debt and Macroeconomic

Peter Hoeller,

Stability

Rossana Merola,

Volker Ziemann

https://dx.doi.org/10.1787/5k8xb76rhstl-en 


\section{Unclassified}

ECO/WKP(2012)80

Organisation de Coopération et de Développement Économiques

Organisation for Economic Co-operation and Development

06-Dec-2012

ECONOMICS DEPARTMENT

English - Or. English

DEBT AND MACROECONOMIC STABILITY

OECD ECONOMICS DEPARTMENT WORKING PAPERS No. 1003

By Douglas Sutherland, Peter Hoeller, Rossana Merola and Volker Ziemann

All Economics Department Working Papers are available through OECD's Internet website at www.oecd.org/eco/Workingpapers

JT03332404

Complete document available on OLIS in its original format

This document and any map included herein are without prejudice to the status of or sovereignty over any territory, to the delimitation of international frontiers and boundaries and to the name of any territory, city or area. 


\section{ABSTRACT/RÉSUMÉ}

\section{Debt and macroeconomic stability}

Debt levels have surged since the mid-1990s and have reached historic highs across the OECD. High debt levels can create vulnerabilities, which amplify and transmit macroeconomic and asset price shocks. Furthermore, high debt levels hinder the ability of households and enterprises to smooth consumption and investment and of governments to cushion adverse shocks. The empirical evidence suggests that when private sector debt levels, particularly for households, rise above trend the likelihood of recession increases. Measures of financial leverage give less warning and typically only deteriorate once the economy begins to slow and asset prices are falling. Government debt typically rises after the onset of a recession, suggesting that there is a migration of debt across balance sheets. Some policies, such as robust micro prudential regulation and frameworks to deal with debt overhangs and maintain public debt at prudent levels, can help economies withstand adverse shocks. Other policy options, such as addressing biases in tax codes that favour debt financing and targeted macro-prudential policies, will help bring down debt levels and address future run ups in debt.

JEL classification: E32; E6; G20; H63

Keywords: Debt; macroeconomic stability

$* * * * * *$

\section{Endettement et stabilité macroéconomique}

Les niveaux d'endettement sont montés en flèche depuis le milieu des années 90 et atteignent des sommets historiques dans la zone de l'OCDE. Un endettement important peut créer des vulnérabilités, qui amplifient et répercutent les chocs macroéconomiques et les variations des prix des actifs. Par ailleurs, dans ces conditions, les ménages et les entreprises n'ont plus la possibilité de lisser leur consommation et leurs investissements et les gouvernements d'amortir les chocs négatifs. L'expérience semble indiquer que, lorsque les niveaux d'endettement du secteur privé, en particulier ceux des ménages, sont supérieurs à la tendance, la probabilité de récession s'accroît. Les indicateurs du levier financier donnent moins de signaux d'alerte et ne se détériorent généralement qu'une fois que l'activité économique commence à se ralentir et que le prix des actifs baissent. La dette publique augmente généralement après le début d'une récession, ce qui laisse penser que la dette migre entre les bilans. Certaines mesures telles que la mise en place d'une réglementation micro-prudentielle efficace et de cadres permettant de faire face au surendettement et de maintenir la dette publique à des niveaux prudents peuvent aider les économies à résister à des chocs défavorables. D'autres actions possibles, comme la correction de certains biais dans les codes des impôts qui favorisent le financement par l'emprunt et des mesures macro-prudentielles ciblées, aideront à réduire les niveaux d'endettement et à contenir le gonflement de la dette dans l'avenir.

Classification JEL: E32 ; E6 ; G20 ; H63

Mots clés : Dette ; stabilité macroéconomique

You can copy, download or print OECD content for your own use, and you can include excerpts from OECD publications, databases and multimedia products in your own documents, presentations, blogs, websites and teaching materials, provided that suitable acknowledgment of OECD as source and copyright owner is given. All requests for commercial use and translation rights should be submitted to rights@oecd.org. 


\section{TABLE OF CONTENTS}

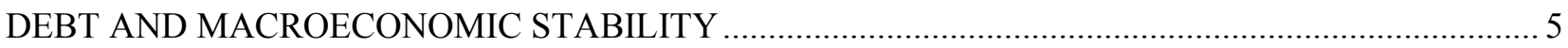

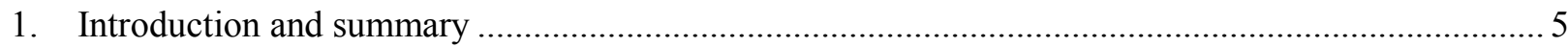

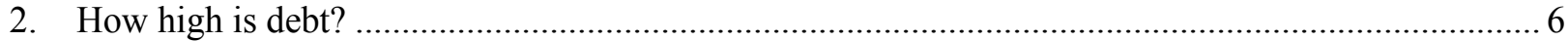

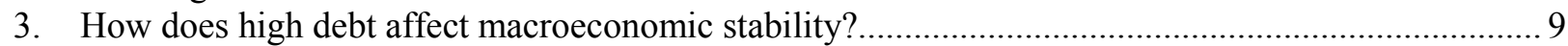

3.1. Balance sheet vulnerabilities and exposure to income shocks .................................................. 9

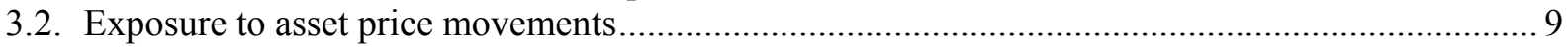



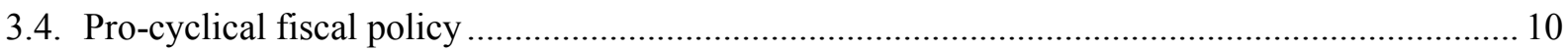

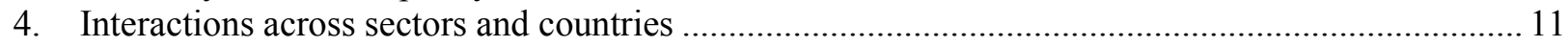





5. What is the empirical evidence of links between debt and macroeconomic stability? .................... 12

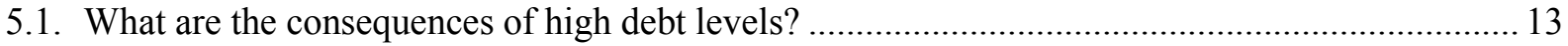

5.2. Does high debt increase the probability of a recession? ............................................................... 14

5.3. What are the characteristics of business cycles when debt is high? ............................................ 16



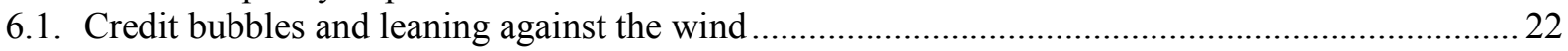

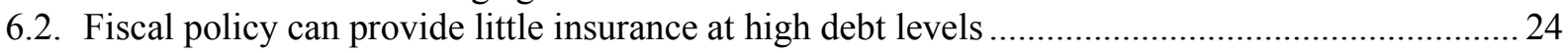

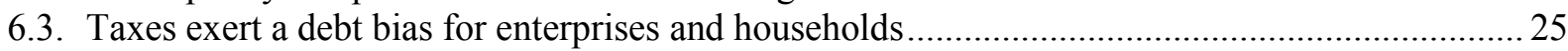

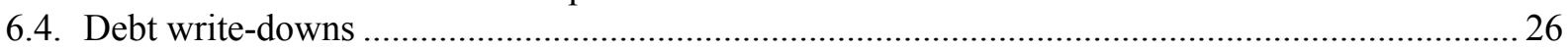

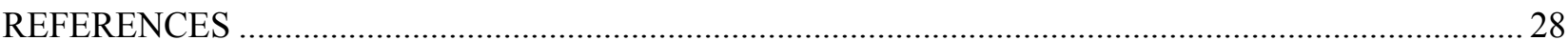

\section{Boxes}

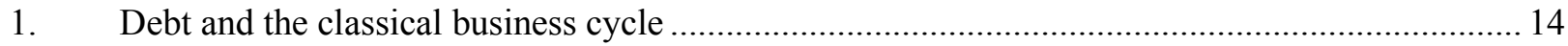

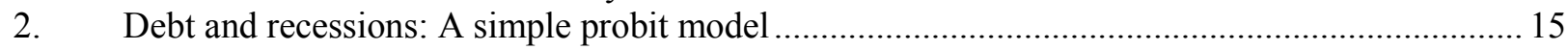

3. Household debt and consumption volatility …................................................................... 18

\section{Tables}

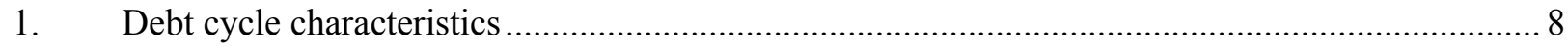

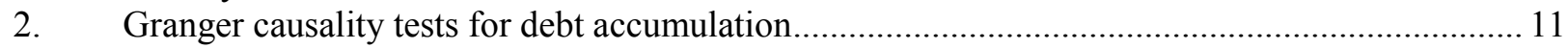

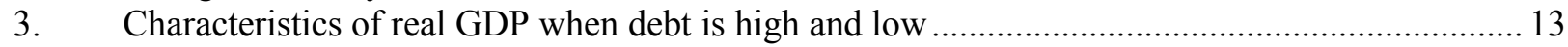



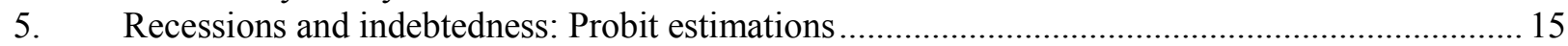



AP.2. Characteristics of real GDP, consumption and investment cycles when debt is high and low ..... 33 


\section{Figures}



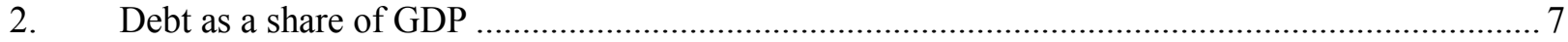



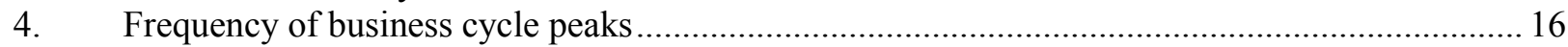

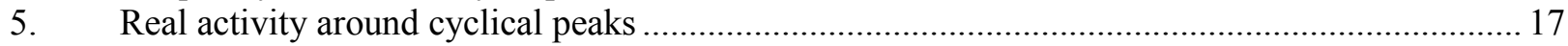

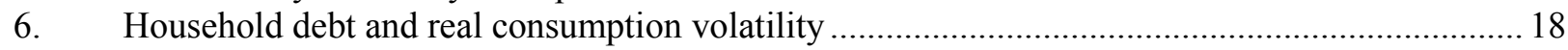

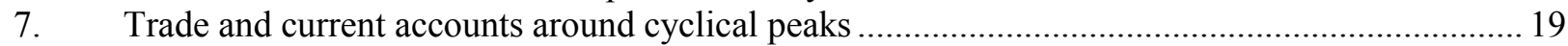

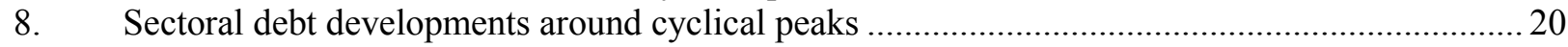

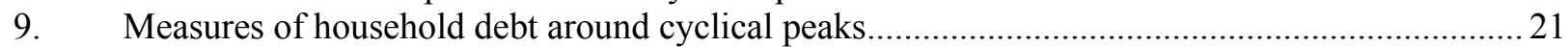

10. Corporate balance sheets around cyclical peaks....................................................................... 22

The statistical data for Israel are supplied by and under the responsibility of the relevant Israeli authorities. The use of such data by the OECD is without prejudice to the status of the Golan Heights, East Jerusalem and Israeli settlements in the West Bank under the terms of international law. 
ECO/WKP(2012)80

\title{
DEBT AND MACROECONOMIC STABILITY
}

\author{
by Douglas Sutherland, Peter Hoeller, Rossana Merola and Volker Ziemann ${ }^{1}$
}

\section{Introduction and summary}

Debt has reached a very high level in many OECD countries. High debt levels affect macroeconomic performance, in an environment where households, the corporate sector and the government individually or in some cases all together need to bring debt down to a sustainable level. Even with progress in deleveraging, debt will remain at elevated levels for a considerable time. The adverse effects of high debt levels extend beyond the impact of deleveraging. High debt can amplify and transmit shocks and also hinder the ability of households and enterprises to smooth consumption and investment and of governments to cushion adverse shocks. Against this backdrop, the focus of this paper is on the consequences of high debt levels for macroeconomic stability.

There are three sets of main findings:

- In the run up to the crisis, debt soared to historic highs in many countries. OECD-wide total financial liabilities now exceed $1000 \%$ of GDP. Countries display considerable heterogeneity in debt levels and leverage, largely reflecting national characteristics. High indebtedness can create vulnerabilities to shocks, exposing households, firms and governments to maturity, currency and liquidity mismatches as well as potential solvency problems. Furthermore, high indebtedness can expose the economy to asset price movements, which can amplify shocks and macroeconomic instability.

- Vulnerabilities appear more pronounced when debt levels, particularly in the household and corporate sectors, are above trend. When private sector debt levels are high recessions are typically longer and deeper, often following a prolonged expansion. While private sector debt levels relative to disposable income or GDP give warning signals before a recession, measures of leverage typically only deteriorate around the start of a recession, in large part due to asset price movements. Government debt typically rises after the onset of a recession, suggesting that there is a migration of debt across balance sheets.

- Policies can help either prevent dangerous run ups in debt or damp macroeconomic or asset price shocks. Micro and macro-prudential regulation can help strengthen banks' balance sheets and allow them to weather shocks. Targeted interventions can help prevent credit booms getting underway. Institutional frameworks, such as fiscal rules and fiscal councils, can help maintain

1. The authors are members of the Economic Department of the OECD. This paper is a revised version of a document prepared for the OECD's project on Debt and Macroeconomic Stability which was presented at a meeting held in October 2012 of Working Party No. 1 of the OECD Economic Policy Committee. Background papers include Merola (2012), Sutherland and Hoeller (2012) and Ziemann (2012). The authors are indebted to the participants of the meeting as well as Jorgen Elmeskov and Jean-Luc Schneider for useful comments and suggestions and to Susan Gascard for excellent editorial support. 
prudent government debt levels, which allow fiscal policy to react to shocks. Removing tax biases which encourage banks, corporations and households holding more debt should help reduce debt levels. Finally, regulations and policies can facilitate debt write-downs, but this may come at the price of a higher cost of capital.

The rest of the paper is structured as follows. In the next section, debt levels and trends are briefly discussed. In the third section the channels through which high debt levels may affect macroeconomic stability are considered. This is followed by a discussion of interactions of debt levels across sectors and countries in section four. In section five, empirical links between debt levels and indicators of macroeconomic stability and instability are considered. In section six, the implications for policy are addressed.

\section{How high is debt?}

Debt as a share of GDP has surged since the mid-1990s. Average total economy financial liabilities have more than doubled since the mid-1990s and gone beyond $1000 \%$ of GDP during the recent crisis (Figure 1). ${ }^{2}$ The size of financial sector liabilities exhibits considerable heterogeneity across countries, being markedly higher in countries which host financial centres (Figure 2, Appendix Table AP.1), but also reflecting the differences in the structure of the financial sector, such as the relative importance of banks, insurance companies and pension funds. Indebtedness of the other sectors also shows considerable cross-country variation, being smallest for government and the household sector. In the case of the household sector, some of the heterogeneity reflects differences in the importance of pension saving, which can lead households to borrow more when purchasing housing. External debt also shows marked cross-country differences, being extremely high in Luxembourg and Ireland but very low in Mexico.

Over the longer term, the build-up in debt has been most marked in the financial sector, particularly following financial market liberalisation. Household debt, while in most cases still relatively modest as a share of GDP, has also grown rapidly, reflecting both the impact of financial market liberalisation and innovation. Government and non-financial enterprise financial liabilities have risen less rapidly, but nonetheless reached high levels. At the same time, macroeconomic instability, as measured by the volatility of output, has tended to fall during the so-called great moderation, but has spiked up sharply during the recent crisis. Indeed, total economy debt appears to be associated with greater macroeconomic volatility, but only at high levels (Figure 3).

2. The choice of measure of financial liabilities or debt can make an important difference. The figure reported is the un-weighted average of non-consolidated total economy financial liabilities (the median is $840 \%$ of GDP). For consolidated accounts, the corresponding figures are just over $1000 \%$ of GDP and $540 \%$ of GDP for the mean and median, respectively. The un-weighted average of debt (gross financial liabilities minus share capital and derivatives) is over $800 \%$ of GDP for non-consolidated accounts and $500 \%$ of GDP for consolidated accounts. 
Figure 1. Financial liabilities



Figure 2. Debt as a share of GDP

Gross financial liabilities, non-consolidated, per cent of GDP, 2010
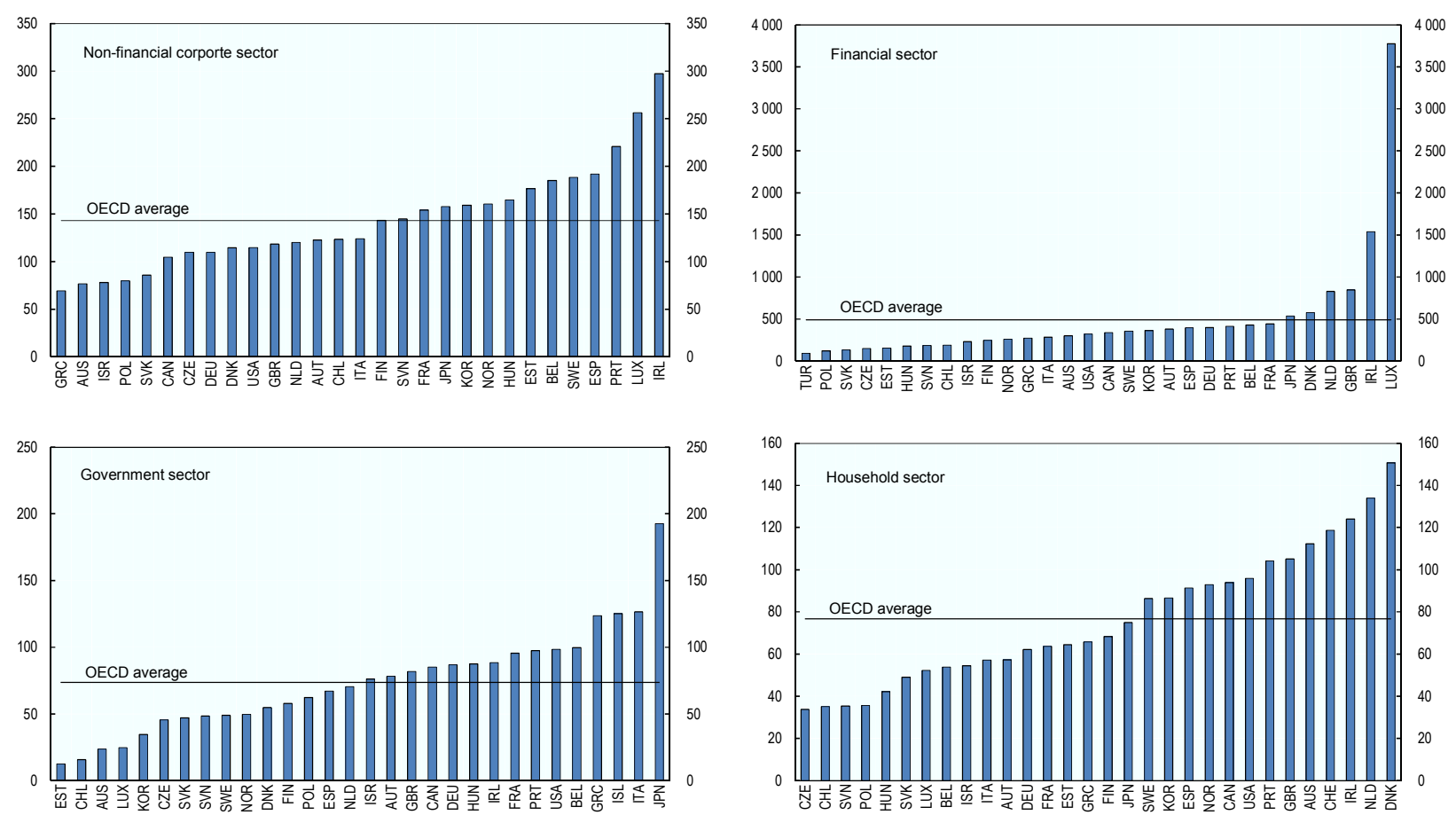

Source: OECD, National Accounts. 
Figure 3. Real GDP volatility and debt

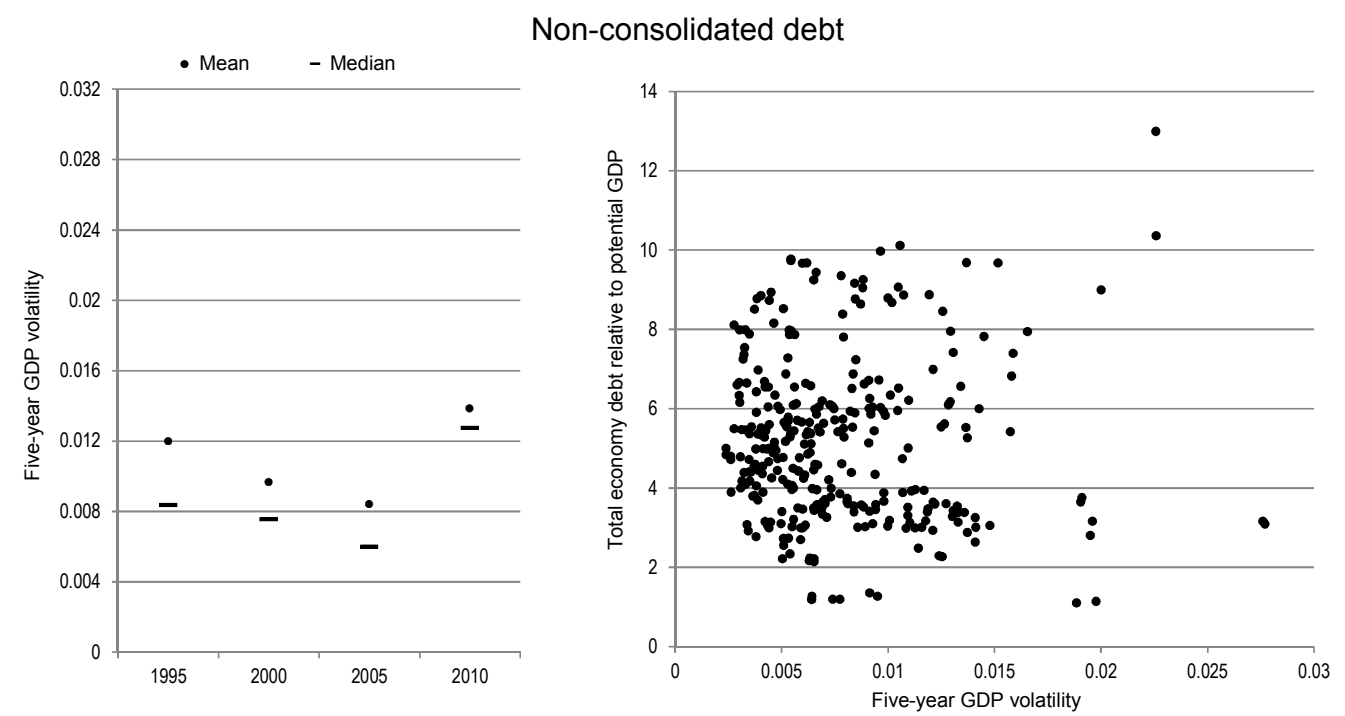

Note: Volatility is the rolling average of the standard deviation of quarterly real growth over the subsequent 20 quarters. Source: OECD National Accounts.

Past developments suggest that elevated debt levels may persist. Total economy debt has risen considerably with only short spells when debt fell as a share of GDP, but debt cycle characteristics vary considerably across the institutional sectors (Table 1). For households and the financial sector, prolonged reductions in debt-to-GDP ratios are rare, with the secular upward trend in debt dominating. The size of the ups and downs in debt levels is more balanced in the government and non-financial corporate sector, but even then the trend was upwards. As compared to deleveraging of the household and financial sector, government and non-financial corporate deleveraging episodes are longer, but even then debt did not decline to levels of the previous trough. The periods when debt levels decline the most are prolonged in the government sector, where the process can continue for over a decade, while the largest reductions occur in the financial and non-financial corporate sectors. Measures of financial leverage, on the other hand, have generally been falling, but they have backed up more recently following the crisis. ${ }^{3}$ Since the crisis erupted in 2007, the debt-to-GDP ratio has come down in only three countries, though the upward movement has decelerated in many others.

Table 1. Debt cycle characteristics

Non-consolidated debt, sample between 1950 (or earliest available year) and 2010

\begin{tabular}{lc|c|c|c|c|c}
\hline & \multicolumn{2}{c|}{ Average increasing } & \multicolumn{2}{c|}{ Average reductions } & \multicolumn{2}{c}{ Large reductions } \\
\cline { 2 - 7 } & $\begin{array}{c}\text { Length } \\
\text { (years) }\end{array}$ & $\begin{array}{c}\text { Size } \\
\text { (\% of GDP) }\end{array}$ & $\begin{array}{c}\text { Length } \\
\text { (years) }\end{array}$ & $\begin{array}{c}\text { Size } \\
\text { (\% of GDP) }\end{array}$ & $\begin{array}{c}\text { Length } \\
\text { (years) }\end{array}$ & $\begin{array}{c}\text { Size } \\
(\% \text { of GDP) }\end{array}$ \\
\hline Total economy & 6.9 & 76.8 & 3.0 & -27.8 & 5.0 & -60.1 \\
Non-financial corporate & 4.4 & 24.6 & 4.5 & -17.9 & 6.6 & -42.1 \\
Financial & 10.7 & 72.5 & 3.4 & -21.5 & 5.6 & -55.3 \\
Government & 6.0 & 22.9 & 5.0 & -14.4 & 8.3 & -34.9 \\
Households & 10.2 & 16.4 & 3.5 & -5.0 & 6.3 & -10.7 \\
\hline
\end{tabular}

Note: The debt cycles are in relation to GDP with the dating determined by a business cycle dating approach, with the peak being followed by at least two years of a declining debt-to-GDP ratio. Large reductions show the average of the largest $25 \%$ of debt level reductions.

Source: OECD National Accounts.

3. In the corporate sector, leverage (defined as financial liabilities less shares and derivatives relative to shares) can fall over prolonged periods, partly reflecting the effects of asset price cycles. 


\section{How does high debt affect macroeconomic stability?}

Debt or leverage can affect macroeconomic performance through several mechanisms. Debt can underpin macroeconomic stability as it allows the smoothing of consumption, investment and tax rates. However, at high debt levels some mechanisms may directly transmit or amplify shocks, while others undermine the capacity to damp shocks. For example, relatively high debt or leverage may make sectors more sensitive to changes in fundamentals. In other cases, already high levels of debt will limit the extent to which additional borrowing can be used to smooth consumption, investment and taxation. The different channels through which high debt can create macroeconomic vulnerabilities are the focus of this section (see also Sutherland and Hoeller, 2012).

\subsection{Balance sheet vulnerabilities and exposure to income shocks}

Debt tends to create balance sheet vulnerabilities due to mismatches and related problems. The vulnerabilities include:

- Maturity mismatch: with a high level of short-term liabilities, borrowers can face problems with rolling over debt (e.g. liquidity risks) and are exposed to an interest rate shock.

- Currency mismatch: if liabilities are denominated in foreign currency, borrowers face exposure to liquidity and exchange rate risks. Liquidity problems emerged during this crisis, when non-US banks had dollar funding problems. While exchange rate risk is generally more of a problem for sovereign borrowers in developing countries, households and the corporate sector in developed countries can also be exposed to this risk. Household borrowing is less likely to be hedged against exchange rate risk, as was the case in some central European countries recently.

- Capital structure problems: corporations with higher reliance on debt rather than equity financing may be less able to cope with adverse revenue shocks.

- Solvency problems: these can arise from maturity and currency mismatches, an inadequate capital structure or simply over-borrowing. Furthermore, pronounced bunching of debt repayments, leading to a large proportion of debt being rolled over simultaneously, may threaten solvency. Thus, while gross debt provides some information on vulnerabilities, the debt structure is also important.

When the state of balance sheets is poor, even relatively small shocks can lead to vulnerabilities, with an adverse income shock squeezing the cash flow available for consumption or investment, while changes in liquidity constraints can amplify the effect of a shock that affects credit supply (Barrell et al., 2006).

\section{2. $\quad$ Exposure to asset price movements}

At higher debt levels exposure to asset price movements can be more pernicious. Shocks can be amplified, particularly when asset price boom-bust cycles act through the value of collateral and associated margin calls, which accentuate cyclical fluctuations and generate debt-deflation pressures. Borrowers using assets as collateral are limited in their ability to borrow if the market value of collateral declines, which can induce deleveraging (Bernanke and Gertler, 1990; Kiyotaki and Moore, 1997). At higher levels of debt, a shock to asset prices (e.g. stocks and housing) will have a large effect on net wealth and thus spending. Estimates of the marginal propensity to consume out of household net wealth range between 2 and $8 \%$, being typically higher in the English-speaking countries (Davis, 2010). Moreover, a collapse in house prices reduces collateral, thereby limiting mortgage equity withdrawal available for consumption 
smoothing. For government, revenues can quickly lose their buoyancy when asset prices fall, as happened during the recent crisis. This can squeeze government budgets and undermine perceptions of sustainability.

\section{3. $\quad$ Financial sector weakness}

In principle, the financial sector can help damp output volatility, especially when idiosyncratic shocks hit. However, when macroeconomic shocks are large or highly correlated, there are limits to the liquidity services that can be provided. For example, highly leveraged banks are less able to damp shocks (Yang and Tsatsaronis, 2012). Balance sheet vulnerabilities can be created not only by macroeconomic distortions, such as fiscal profligacy or exchange-rate misalignment, but also by poor micro and macro prudential regulation, connected lending, governments interfering in the credit allocation process and the issuing of guarantees which encourage lending. As banks are funding less from bank deposits, the greater role for securities markets has also created a new set of vulnerabilities as they have been prone to abrupt changes in liquidity and corresponding difficulties of valuation. In addition, counterparty risks have been prominent during the economic crisis. When they materialise, they can cause spill-over and contagion effects because a default leads to falling asset prices which then lead to losses that depress financial institutions' equity. Consequently, they are forced to sell assets in fire sales, which, in turn, further depress asset prices and increase losses.

\subsection{Pro-cyclical fiscal policy}

Increased government borrowing during a downturn cushions the effects of a large, adverse shock. However, at high government debt levels, there appear to be limits to the ability to stabilise the economy, potentially raising macroeconomic volatility. A number of factors reduce the effectiveness of fiscal policy at high debt levels. Indeed earlier work on fiscal reaction functions for the WP1 project on counter-cyclical economic policy found that fiscal policy becomes pro-cyclical at high levels of financial liabilities (Égert, 2010).

- At high government debt levels, fiscal policy stabilisation may become less effective due to Ricardian behaviour of households and firms. Recent empirical results (Röhn, 2010) suggest that the private saving offset becomes larger when debt is above $75 \%$ of GDP.

- Government borrowing can lead to crowding out. Empirical estimates of the effect of government borrowing on interest rates suggest that the term premium is non-linear (Laubach, 2009; Égert, 2010; Turner and Spinelli, 2011). In this context, government borrowing to stabilise aggregate demand may be counteracted by a higher cost of capital deterring investment and consumption. On the other hand, and particularly when balance sheets are impaired in other sectors and liquidity constraints bite, fiscal policy may have very large multipliers (DeLong and Summers, 2012).

- At very high debt levels, doubts about government solvency will arise (Corsetti et al., 2011). With fears of sovereign default raising interest rates for firms and households, crowding out effects can be exacerbated by news of weakening economic performance, as this makes fiscal consolidation targets harder to attain. The private sector may also be affected through their balance sheet as government debt prices fall in reaction to increased fears of default. 
ECO/WKP(2012)80

\section{Interactions across sectors and countries}

\subsection{Spillovers across sectors}

As experienced in the financial crisis, a shock to the apparently small sub-prime market transformed into a full-blown crisis in large part due to balance sheet vulnerabilities. At high levels, debt can cause such vulnerabilities to migrate and cascade across sectors. When debt is high in a single sector or even in small parts of a sector, the impact of a shock may nonetheless be widespread due to the linkages between sectors.

Ultimately, as seen in the recent crisis, the government can be placed in an unenviable position of having to rescue the financial and even parts of the non-financial corporate sector. More indirectly, but quantitatively more important, government budgets are affected by cyclical weakness as other sectors deleverage, through automatic budget reactions as well as counter-cyclical fiscal policy. Recent experience demonstrates that, at high initial government debt levels, contagion from the private to the public sector can force governments to become pro-cyclical during economic downturns. Simple Granger causality tests suggest that even when excluding the recent crisis, run-ups in corporate borrowing (in both the financial and to a lesser extent the non-financial sector) tend to "Granger cause" increases in public sector debt (Table 2). That the government sector "Granger causes" household debt could reflect consumption smoothing. On the other hand, the result that rapid growth in household debt is followed by a boost in financial sector liabilities is difficult to explain.

Table 2. Granger causality tests for debt accumulation

1965-2005, non-overlapping five-year change in debt levels as \% of GDP

\begin{tabular}{lc|c}
\hline Null hypothesis & F-statistic & Probability \\
\hline The financial sector does not Granger cause the non-financial sector & 1.25 & 0.31 \\
\hline The non-financial sector does not Granger cause the financial sector & 1.12 & 0.35 \\
The government sector does not Granger cause the non-financial sector & 0.08 & 0.47 \\
\hline The non-financial sector does not Granger cause the government sector & $\mathbf{4 . 7 9}$ & $\mathbf{0 . 0 2}$ \\
The household sector does not Granger cause the non-financial sector & 0.81 & 0.46 \\
\hline The non-financial sector does not Granger cause the household sector & $\mathbf{2 . 5 5}$ & $\mathbf{0 . 1 0}$ \\
The government sector does not Granger cause the financial sector & 1.37 & 0.28 \\
The financial sector does not Granger cause the government sector & $\mathbf{8 . 7 3}$ & $\mathbf{0 . 0 0}$ \\
The household sector does not Granger cause the financial sector & $\mathbf{9 . 3 2}$ & $\mathbf{0 . 0 0}$ \\
The financial sector does not Granger cause the household sector & 1.06 & 0.36 \\
The household does not Granger cause the government sector & 0.38 & 0.69 \\
\hline The government sector does not Granger cause the household sector & $\mathbf{4 . 5 3}$ & $\mathbf{0 . 0 2}$ \\
\hline
\end{tabular}

Note: Granger causality tests performed with two lags. The Granger causality test tests whether including lagged information of one variable can help explain the current value of another variable. It does not prove by itself causality. In the table the test statistic (F-statistic) and associated probability are displayed. A low F-statistic and large probability does not reject the null hypothesis that the information of lagged debt in one sector does not help explain the debt in the other sector. Conversely, a high F-statistic and low probability implies that information on lagged debt in one sector does help explain debt developments in another sector.

Even in the absence of direct migration of balance sheet problems, concerns about the health of balance sheets in one sector can have implications for others. Household, corporate or government balance sheets affect the banking system, particularly when the banking sector has too little capital cushion. For example, fears about sovereign solvency can provoke runs on the banking system. Balance sheet vulnerabilities can also lead to self-fulfilling runs or sudden stops, when foreign capital flows dry up (Mendoza and Smith, 2006). Moreover, when corporate and household debt is elevated, a shock can induce forced cuts in investment, employment and consumption with implications for government revenues and spending. In this light, when private sector balance sheets are in poor health the effect of an adverse shock 
is likely to be felt more widely. Due to such repercussions, creditors can view private and public debt together when a crisis erupts (Diaz-Alejandro, 1985).

When several sectors with large debt overhangs pursue deleveraging simultaneously, the process is likely to be prolonged and amplified. For example, the quality of bank balance sheets matters for credit supply during recessions (Jimenéz et al., 2012) because bank deleveraging can reduce the supply of credit. When households and the non-financial corporate sector are also highly leveraged the impact of bank deleveraging can be severe. This constellation will amplify and propagate large shocks. For example, in Japan, post-bubble defaults on corporate loans and worsening capital positions led banks to tighten credit conditions significantly. The ensuing substantial deleveraging of the non-financial corporate sector continued throughout the 1990s and into the 2000s.

\subsection{International transmission}

Over time, external assets and liabilities have grown, with debt accounting for a large share of liabilities (particularly in the United Kingdom). Why such large two-way debt flows exist is not well understood (Obstfeld, 2012). They can have positive effects on market functioning, but may also be related to tax shifting and regulatory arbitrage. If investors shift funds to safe havens, liquidity will evaporate and counterparty risks rise, which can threaten financial stability, with consequent effects on activity. Empirical work suggests that greater financial openness exacerbates the effect of adverse financial shocks on real output (Aizenman et al., 2011).

The transmission of financial crises and exposure to foreign currency denominated debt can increase vulnerabilities and amplify macroeconomic volatility (Korinek, 2011). Before the recent financial crisis financial market integration proceeded rapidly. During the crisis, many banks became more exposed to maturity and currency mismatches, particularly for those banks reliant on cross-border wholesale financing (Tressel, 2010). But the crisis did not only affect those banks. Due to cross holdings, shocks to the financial sector can be transmitted quickly across countries. Negative shocks in one country can worsen the perception of financial market investors about countries with similar characteristics, while the deterioration in the balance sheet of financial institution can push them to sell external assets or to recall external loans to comply with internal rules or with prudential regulations. Ahrend and Goujard (2011) found that bank balance sheet driven contagion shocks are important and their effects are stronger when financial market integration is tighter. Cetorelli and Goldberg (2012), using data from US branches of foreign banks, show that the parent bank's exposure to asset-backed commercial paper had an impact on liquidity management. Banks most exposed were more likely to transfer money from the branches, with consequent declines in lending in the host country. Giannetti and Laeven (2012) find that in the syndicated loan market foreign banks export shocks in their home markets to their host markets.

\section{What is the empirical evidence of links between debt and macroeconomic stability?}

The links discussed above suggest that high debt can lead to vulnerabilities and undermine macroeconomic stability. An adverse shock can tip the economy into recession. In this section, the links between debt and recessions are first considered before examining differences between high and low-debt business cycles. Defining high and low debt levels is complicated as financial market liberalisation and innovation have allowed debt levels as a share of GDP to rise over time, while differences across countries often reflect features particular to a given country (such as the extent of pension funding or the prevalence of interest only mortgages). Ideally, high and low debt levels would be set by fundamentals, but there is often little consensus on what these are. Against this background, to account for the upward trend in debt levels, which were partly driven by greater debt-holding capacity and the idiosyncratic features of the financial sectors across different countries, high and low debt periods are defined as deviations from the trend. First debt levels are calculated in relation to potential GDP to avoid cyclical movements in the 
denominator driving debt-to-GDP ratios down (up) when output is above (below) trend. In order to eliminate longer-term secular trends in the debt-to-potential GDP ratios a HP filter using a (quarterly) lambda of 400000 was used to extract the longer-term "cyclical" component. Unavoidably, using this method encounters the end-point problem, which given the severity of the recent recession is an important consideration.

A small industry has emerged examining the impact of government debt on growth. Picking up the arguments of Reinhart and Rogoff (2010), several studies find that high government debt undermines growth, sometimes in a non-linearly fashion (Caner et al., 2010; Kumar and Woo, 2010; Checherita and Rother, 2010; and Cecchetti et al., 2011). While these studies suggest important effects, particularly as government debt-to-GDP ratios exceed thresholds above $75 \%$ of GDP, pinning down a robust threshold is difficult (Égert, 2012). The evidence for growth-diminishing effects of debt held by other sectors has been less explored. An exception is Cecchetti et al. (2011). Their findings were largely inconclusive.

\subsection{What are the consequences of high debt levels?}

Recessions occur more frequently when debt levels are high (Table 3). The frequency of recessions during total economy high-debt periods is almost twice as high as during low-debt periods (45 against 25 recessions). The expansions before the high-debt recessions are typically longer and larger, but the recessions are on average more severe, when household and corporate sector debt is high. Indeed, for high private-sector debt cycles there is a potential trade-off between the length of the expansion and the severity of the subsequent recession, with the trade-off worsening during the recent cycle (Box 1). These findings are consistent with Jorda et al. (2011) who, considering much longer time spans, find that more severe recessions follow expansions with larger build-ups of leverage. This is especially the case for real investment cycles, for which the size of the downturn is particularly pronounced relative to low-debt recessions (Appendix Table AP.2). On the other hand, when the level of government debt is above trend recessions tend to be less frequent and less severe, reflecting that, at the top of the business cycle, budgetary positions are often unduly flattering. For example, revenue buoyancy related to surging asset prices can help contain government debt levels from rising, but the situation can quickly reverse with the onset of a recession.

Table 3. Characteristics of real GDP when debt is high and low

Earliest available year to 2010

\begin{tabular}{lc|cc|cc}
\hline & \multicolumn{4}{c}{ GDP } \\
\cline { 2 - 5 } & $\begin{array}{c}\text { Number of } \\
\text { recessions }\end{array}$ & $\begin{array}{c}\text { Contraction } \\
\text { Average } \\
\text { size }\end{array}$ & $\begin{array}{c}\text { Average } \\
\text { length }\end{array}$ & $\begin{array}{c}\text { Previous expansion } \\
\text { Average } \\
\text { size }\end{array}$ & $\begin{array}{c}\text { Average } \\
\text { length }\end{array}$ \\
\cline { 2 - 6 } $\begin{array}{l}\text { Total economy debt } \\
\text { High }\end{array}$ & 45 & -4 & 4 & 26 & 29 \\
Low & 25 & -2 & 4 & 16 & 20 \\
Household debt & 42 & -4 & 4 & 28 & 31 \\
High & 32 & -2 & 3 & 15 & 18 \\
Low & 27 & -2 & 3 & 18 & 23 \\
Government debt & 48 & -4 & 4 & 25 & 27 \\
High & 41 & -5 & 4 & 27 & 30 \\
Low & 33 & -2 & 4 & 16 & 19 \\
Financial sector debt & & & & & \\
High & & -4 & 4 & 25 & 28 \\
Low & 46 & -3 & 4 & 19 & 23 \\
Non-financial sector debt & 21 & & & & \\
High & & & & & \\
Low & & & & & \\
\hline
\end{tabular}

Note: The cycle is the classical business cycle (the algorithm used is described in Box 1). The size is the cumulative percentage change in the level and the length is the number of quarters of the contraction or expansion phases. 


\section{Box 1. Debt and the classical business cycle}

Following Canova (2007), a simple algorithm is used to identify classical business cycles for the level of real GDP, consumption and investment. ${ }^{1}$ Having identified turning points, the characteristics of expansions and (technical) recessions are determined in terms of length, measured by the number of quarters, and size, measured by the cumulative percentage change of the level of real GDP, consumption and investment.

In addition to the length and size of expansions and contractions, the ratio of the length and size between expansions and contractions provides information about asymmetries of business cycles. The following demonstrates how even small changes in the sample can alter the relative properties of expansions and contractions. For the total sample, the asymmetries between expansions and contractions in both length and amplitude are more pronounced for output and consumption than investment. Investment cycles are more volatile with the asymmetry of length and amplitude considerably smaller (Table 4). In comparison with all cycles, when total economy debt levels are above trend, cycle expansions are longer and somewhat larger relative to contractions. That high-debt expansions of real GDP, consumption and investment were larger relative to contractions is more clear-cut, when omitting the last cycle from the sample.

In sum, there appears to be some association of business cycle characteristics with debt levels. When debt is higher the expansion was often prolonged relative to the contraction. However, when the last cycle is included the severity of recessions considerably offset the advantage of the preceding long expansion.

Table 4. Business cycle asymmetries

Length in quarters and size in cumulative percentage change during expansions relative to contractions

\begin{tabular}{|c|c|c|c|c|c|c|}
\hline & \multicolumn{2}{|c|}{ GDP } & \multicolumn{2}{|c|}{ Consumption } & \multicolumn{2}{|c|}{ Investment } \\
\hline & Length & Size & Length & Size & Length & Size \\
\hline End-year of analysis & \multicolumn{6}{|c|}{ Total economy debt, all cycles } \\
\hline 2010 & 5.9 & 7.1 & 6.0 & 7.3 & 2.3 & 2.3 \\
\hline 2005 & 5.7 & 9.0 & 5.7 & 7.8 & 2.3 & 2.6 \\
\hline End-year of analysis & \multicolumn{6}{|c|}{ Total economy debt, debt above trend } \\
\hline 2010 & 7.8 & 7.3 & 7.7 & 10.3 & 3.2 & 3.3 \\
\hline 2005 & 8.5 & 22.8 & 8.5 & 24.2 & 3.6 & 6.0 \\
\hline
\end{tabular}

Note: 2010 and 2005 describe the terminal date in the sample used to calculate the business cycle asymmetries.

1. The algorithm requires smoothing the series of interest (GDP, investment and consumption) using a five point Spencer curve to eliminate the impact of idiosyncratic and high frequency volatility. Second, a dating rule identifies peaks (troughs) if they are larger (smaller) than the observations for the preceding and following two quarters. Third a censoring rule ensures that the peaks and troughs alternate and that the duration of the cycles is meaningful (at least five quarters in length from peak to peak or trough to trough) and the amplitude of the movement from peak to trough or trough to peak is larger than $1 \%$.

\subsection{Does high debt increase the probability of a recession?}

In order to examine whether debt levels had an informative content before the start of past recessions, a probit model examines the role of debt in a parsimonious specification using the yield curve augmented by debt variables as explanatory variables (Table 5, Box 2). Notwithstanding the parsimonious specification, the estimations show that the yield spread has the expected negative sign and that debt levels have some predictive power. High levels of private sector debt increase the likelihood of a recession occurring during the following year.

The marginal effects reported in Table 5 indicate the strength that a change in the explanatory variables has on the probability of a recession occurring, evaluated at the mean of the variables. The effect on the probability of recession is strongest for household debt. Furthermore, the probability of recessions rises rapidly when household debt moves further from trend, reflecting the non-linearity of the probit estimator. The marginal effect becomes larger, rising to over 3. As a result, while the predicted recession probability is around $10 \%$ when household debt is at trend it rises to over $40 \%$ once it rises above trend by $10 \%$ of GDP, which while the effect is large, such an increase above trend is relatively infrequent. The marginal effects for the other sectors and for total economy debt are less powerful, though rising non-financial corporate debt has a somewhat stronger effect than either rising total economy debt or 
financial sector debt. The effect of higher levels of government debt relative to trend is negative and reasonably strong, but when using different measures of debt, the effect is not significant (Box 2).

Table 5. Recessions and indebtedness: Probit estimations

Dependent variable is whether a (technical) recession occurs in the following year

\begin{tabular}{|c|c|c|c|c|c|c|c|c|c|c|c|c|c|}
\hline \multirow[b]{2}{*}{ Yield curve } & \multirow{2}{*}{$\begin{array}{l}\text { Coefficient } \\
-0.041^{*}\end{array}$} & \multirow{2}{*}{$\begin{array}{c}\begin{array}{c}\text { Marginal } \\
\text { effect }\end{array} \\
-0.015\end{array}$} & \multicolumn{2}{|c|}{ Coefficient } & \multirow{2}{*}{$\begin{array}{c}\begin{array}{c}\text { Marginal| } \\
\text { effect }\end{array} \\
-0.013\end{array}$} & Coefficient & \multirow{2}{*}{\begin{tabular}{|c|}
$\begin{array}{c}\text { Marginal } \\
\text { effect }\end{array}$ \\
-0.016
\end{tabular}} & \multicolumn{2}{|l|}{ Coefficient } & \multirow{3}{*}{\begin{tabular}{|c|}
$\begin{array}{c}\text { Marginal } \\
\text { effect }\end{array}$ \\
-0.018
\end{tabular}} & \multicolumn{2}{|c|}{ Coefficient } & \multirow{3}{*}{$\begin{array}{c}\begin{array}{c}\text { Marginal } \\
\text { effect }\end{array} \\
-0.015\end{array}$} \\
\hline & & & -0.065 & ** & & -0.074 * & & -0.084 & ** & & -0.073 & * & \\
\hline & 0.038 & & 0.039 & & & 0.04 & & 0.038 & & & 0.041 & & \\
\hline \multirow[t]{2}{*}{ Total economy } & $0.494^{*}$ & 0.106 & & & & & & & & & & & \\
\hline & 0.038 & & & & & & & & & & & & \\
\hline \multirow[t]{2}{*}{ Household debt } & & & 8.316 * & *** & 1.712 & & & & & & & & \\
\hline & & & 1.915 & & & & & & & & & & \\
\hline \multirow[t]{2}{*}{ Government debt } & & & & & & $-2.04 \quad * *$ & -0.451 & & & & & & \\
\hline & & & & & & 1.02 & & & & & & & \\
\hline \multirow[t]{2}{*}{$\begin{array}{l}\text { Financial sector } \\
\text { debt }\end{array}$} & & & & & & & & 0.494 & * & 0.108 & & & \\
\hline & & & & & & & & 0.294 & & & & & \\
\hline \multirow{2}{*}{\multicolumn{2}{|c|}{ Non-financial sector debt }} & & & & & & & & & & 2.119 & $* * *$ & 0.447 \\
\hline & & & & & & & & & & & 0.655 & & \\
\hline \multirow[t]{2}{*}{ Constant } & $-1.048^{* * *}$ & & -1.084 & *** & & $-1.03^{* * *}$ & & -1.019 & $\star * * *$ & & -1.06 & $\star \star \star *$ & \\
\hline & 0.079 & & 0.08 & & & 0.078 & & 0.076 & & & 0.083 & & \\
\hline Observations & 475 & & 500 & & & 500 & & 488 & & & 457 & & \\
\hline $\begin{array}{l}\text { Correctly classified } \\
\text { recessions/ } \\
\text { non-recession perioc }\end{array}$ & $\begin{array}{l}64.0 \\
\text { ds }\end{array}$ & & 63.0 & & & 59.4 & & 61.1 & & & 64.3 & & \\
\hline $\begin{array}{l}\text { Correctly classified } \\
\text { recessions in \% }\end{array}$ & 65.2 & & 62.3 & & & 61.1 & & 62.9 & & & 58.7 & & \\
\hline
\end{tabular}

Note: Debt is measured as the "cyclical" component of debt relative to potential output. Robust standard errors are shown below the coefficient estimate with ${ }^{* * *},{ }^{* *},{ }^{*}$ denoting significance at the 1,5 and $10 \%$ significance levels, respectively. The marginal effect is the effect on the probability of a recession occurring due to a small change in the explanatory variable and evaluated at the means of the explanatory variables.

\section{Box 2. Debt and recessions: A simple probit model}

A simple probit model can throw some light on the impact of non-consolidated debt on past recessions. In a number of studies, the yield curve appears to contain useful information in signalling future recessions (Estrella, Rodrigues and Schich, 2003; Rudebusch and Williams, 2009; Wheelock and Wohar, 2009). In a simple benchmark probit estimation the dependent variable is a binary variable taking the value of 1 if a recession occurs in the following year and 0 otherwise. The variables to predict a turning point include the yield curve and debt for the total economy and for the different sectors measured as the cyclical component of debt to potential GDP.

The results indicate that when private sector debt, particularly of the household and the non-financial sector, is high relative to trend the probability of a recession occurring in the following year increases. Unlike the private sector, which has benefited from financial innovation thereby allowing it to accumulate more debt over time, the public sector may have been less influenced by such developments. In this context, removing a trend from government debt developments may be less justified. When the government debt variable in the probit is set in relation to potential GDP or the average over the sample, high government debt levels are no longer associated with a lower probability of recession and the effect is neither statistically significant nor large.

A number of robustness tests were performed (Sutherland and Hoeller, 2012). First, the results are robust to dropping individual countries from the estimation. Second, similar results hold when the panel excludes the recent crisis. Third, longer lags were imposed, though in this case only household debt above trend remained a significant predictor of recessions. Overall, however, the performance of the simple probit model is relatively poor, even within sample. While the estimation captures the majority of recessions, it nonetheless predicts too many.

1. While ex post evaluations of forecasting performance highlight that simple indicators can perform well, the best indicator changes over time (Banerjee and Macellino, 2006; Stock and Watson, 2001). 
These results suggest that high debt levels may play a role in downturns, but with differences between the sectors. The analysis does not allow an examination of the impact of debt levels on the size of economic downturns. To examine this in greater detail the next section considers developments during business cycles with different levels of debt.

\subsection{What are the characteristics of business cycles when debt is high?}

To examine the characteristics of debt during the business cycle, this section focuses on the deviation cycle, as it takes into account the effects of debt on growth that may not be strong enough to tip a high-growth economy into a recession but still strong enough to slow it considerably. Even after accounting for the upward trend in debt levels, many high-debt business cycles have occurred recently, with previous episodes also often clustered (Figure 4, Ziemann, 2012). ${ }^{4}$

\subsubsection{Economic activity during high and low-debt cycles}

When considering total debt, real activity moves further above trend at the peak of high-debt than low-debt cycles (Figure 5). Real GDP at 4\% above trend is roughly double the above-trend figure experienced at the peak of low-debt cycles. While the subsequent slowdown sees activity dropping below trend after four quarters it remains depressed for the high-debt cycles whereas it returns to trend during low-debt cycles. The failure to return to trend is a result that is largely driven by the severity of the last cycle. When the last cycle is excluded, the differences between low and high-debt cycles for GDP are less apparent, possibly reflecting the greater effectiveness of stabilisation policy earlier on. Less synchronisation of recessions across countries and the lower frequency of concomitant financial market crises certainly have also played a role.

Figure 4. Frequency of business cycle peaks
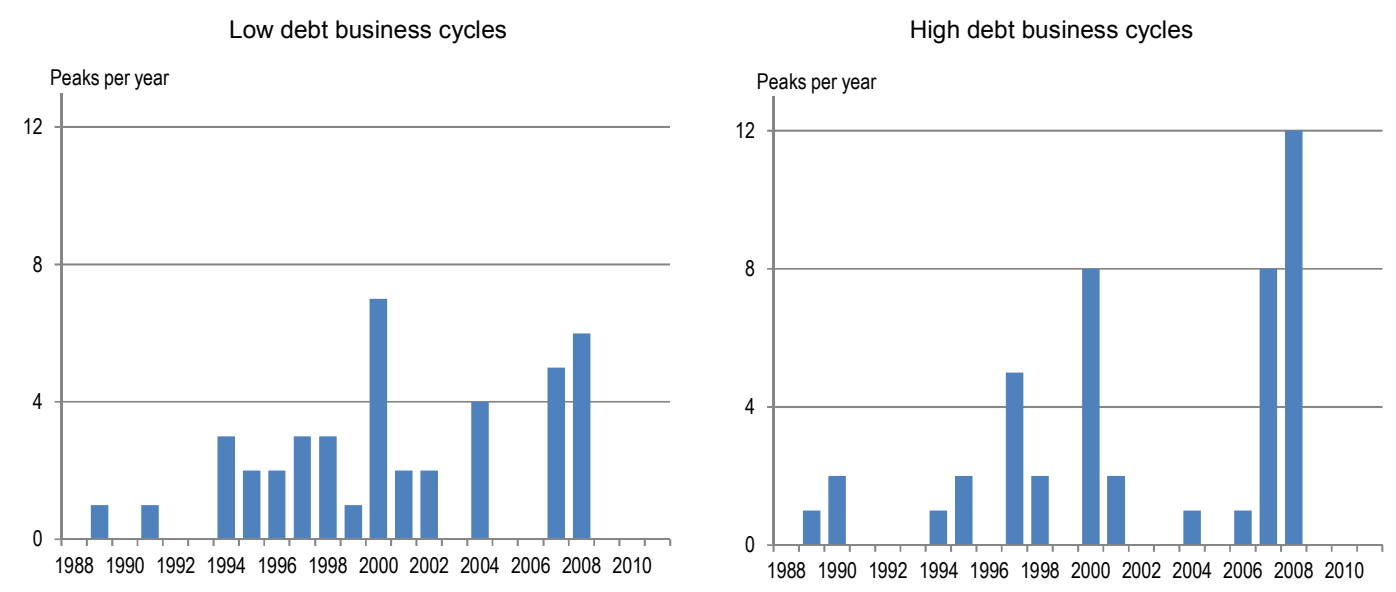

Note: Business cycles are deviation cycles with the low and high-debt cycles determined by the level of the "cyclical" component of debt to potential output at the peak of the cycle.

4. The sample is split to have an equal number of low and high-debt business cycle peaks. The cut off is the $70^{\text {th }}$ percentile of the cyclical component of the debt-to-GDP ratio. 
Figure 5. Real activity around cyclical peaks
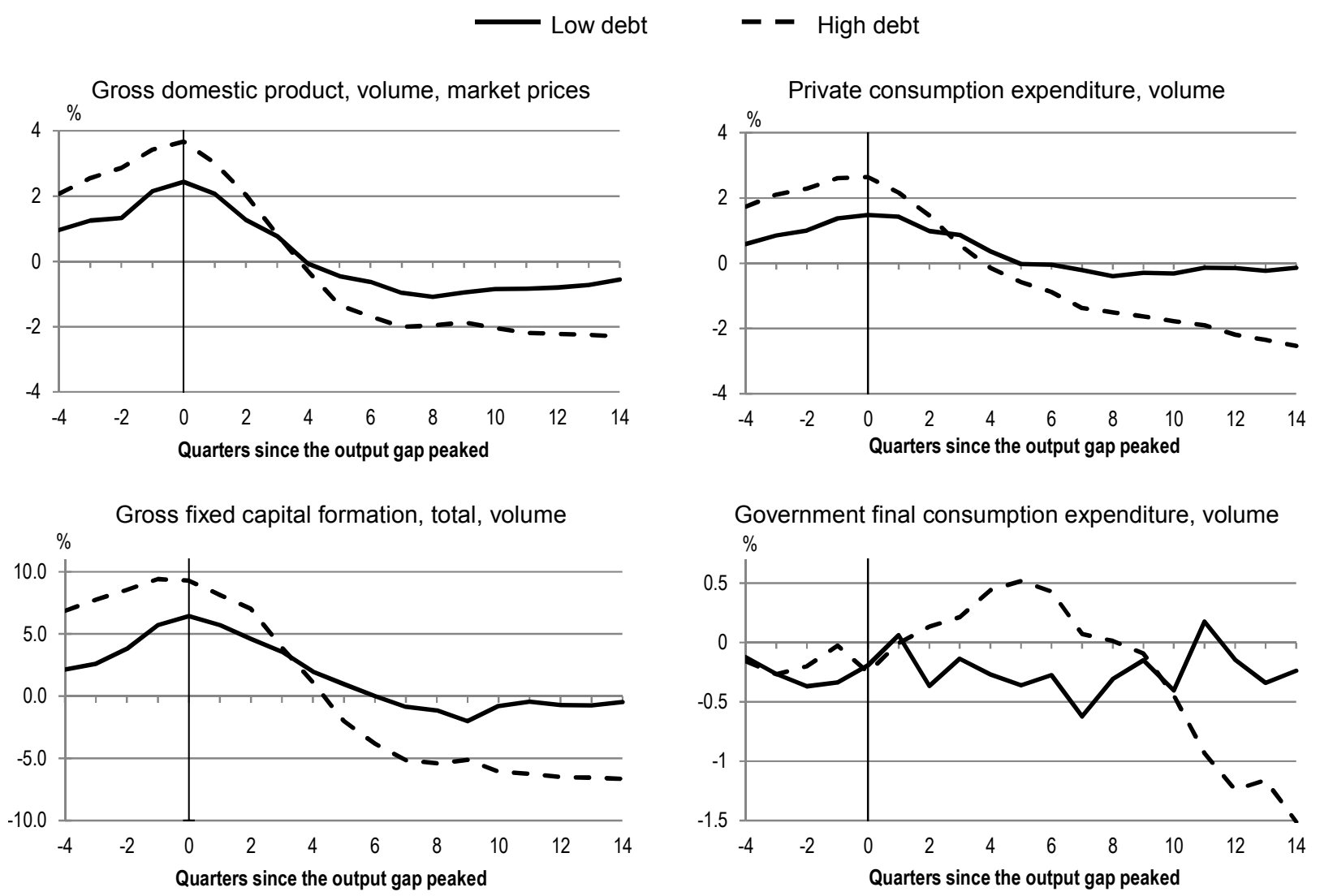

Note: The vertical line denotes the peak of the deviation business cycle. Low and high debt cycles are determined by the level of the "cyclical" component of debt to potential output at the peak of the cycle. The lines correspond to average percentage deviation paths for the corresponding variable relative to the long-term trend.

Similar dynamics are also discernible for real consumption and the role of debt is further corroborated by empirical evidence which suggests that consumption volatility is elevated when household debt is high relative to income or GDP (Box 3). Also gross fixed capital investment is noticeably more above trend and declines much more during high-debt cycles (Figure 5). The same is the case for housing investment, which rises during low-debt cycles barely above trend (Ziemann, 2012). The rapid decline in housing investment after the peak in high-debt cycles is likely affected by weakening house prices that are more volatile during high-debt cycles. The pronounced effect of high debt cycles on GDP, consumption and investment during the downturn may reflect the role of fiscal policy, which, judged by the evolution of government consumption, turns strongly restrictive after a while. Again, this may be a result that is driven by the latest cycle.

The pattern for investment around high-debt turning points echoes findings that investment falls more after the onset of a financial crisis when the debt-to-equity ratio is high (Davis and Stone, 2004). Econometric evidence, reported in Sutherland and Hoeller (2012), also suggests that when short-term borrowing is large relative to share capital subsequent real investment volatility is more pronounced. This is consistent with evidence for some EU countries that greater reliance on bank financing is associated with higher investment volatility, while equity financing appears to reduce volatility (Mullineux et al., 2011). 


\section{Box 3. Household debt and consumption volatility}

Measures of (symmetric) volatility provide a complementary way to examine the relationship between debt and macroeconomic stability. Following the approach of Blanchard and Simon (2001) the 20 quarter rolling standard deviation of the growth rate of real consumption is used as the measure of macroeconomic volatility. The bivariate relationship between household debt and real consumption volatility tends to be more pronounced in countries with higher as well as rising levels of household debt or leverage (debt to disposable income ratio) (Figure 6). Simple econometric analysis examining levels and changes in household debt and leverage ratios suggests that higher as well as rising levels are associated with larger subsequent real consumption volatility, whereas rising household debt is associated with lower real consumption volatility in the same period (Sutherland and Hoeller, 2012). Unsurprisingly, when looking at the more detailed balance sheet items, these relationships are driven by household loans.

Figure 6. Household debt and real consumption volatility

Non-consolidated debt


Note: Consumption volatility is the rolling average of the standard deviation of quarterly real consumption growth over the subsequent 20 quarters. The figures show non-overlapping five-year periods.

Source: OECD, National Accounts, OECD Economic Outlook 91 database.

Trade is also substantially more volatile during high than low-debt cycles. Real exports are at a similar level at the peak of the business cycle with respect to trend, while imports exceed the long-term trend markedly in high-debt business cycles. As a result, current account deficits are large in high-debt episodes and swing considerably after the peak of the deviation cycle (Figure 7). As the output gap closes and turns negative, imports fall markedly and the current account balance improves.

\subsubsection{Debt and leverage developments during high and low-debt cycles}

Around the turning points in the deviation cycle, debt held by the private sector behaves quite differently from government debt (Figure 8). During high-debt business cycles, private sector debt is, not surprisingly, considerably above trend going into the slowdown. This pattern also holds when using different business cycle definitions (Ziemann, 2012). Government debt, on the other hand, rises from below trend after the turning point, with the rise more pronounced for high-debt business cycles, reflecting greater stabilisation efforts and bail out costs. This is also consistent with the findings reported above that fewer recessions occur when government debt levels are elevated and that, following a build-up in debt, the government assumes debt held by the private sector. 
Figure 7. Trade and current accounts around cyclical peaks

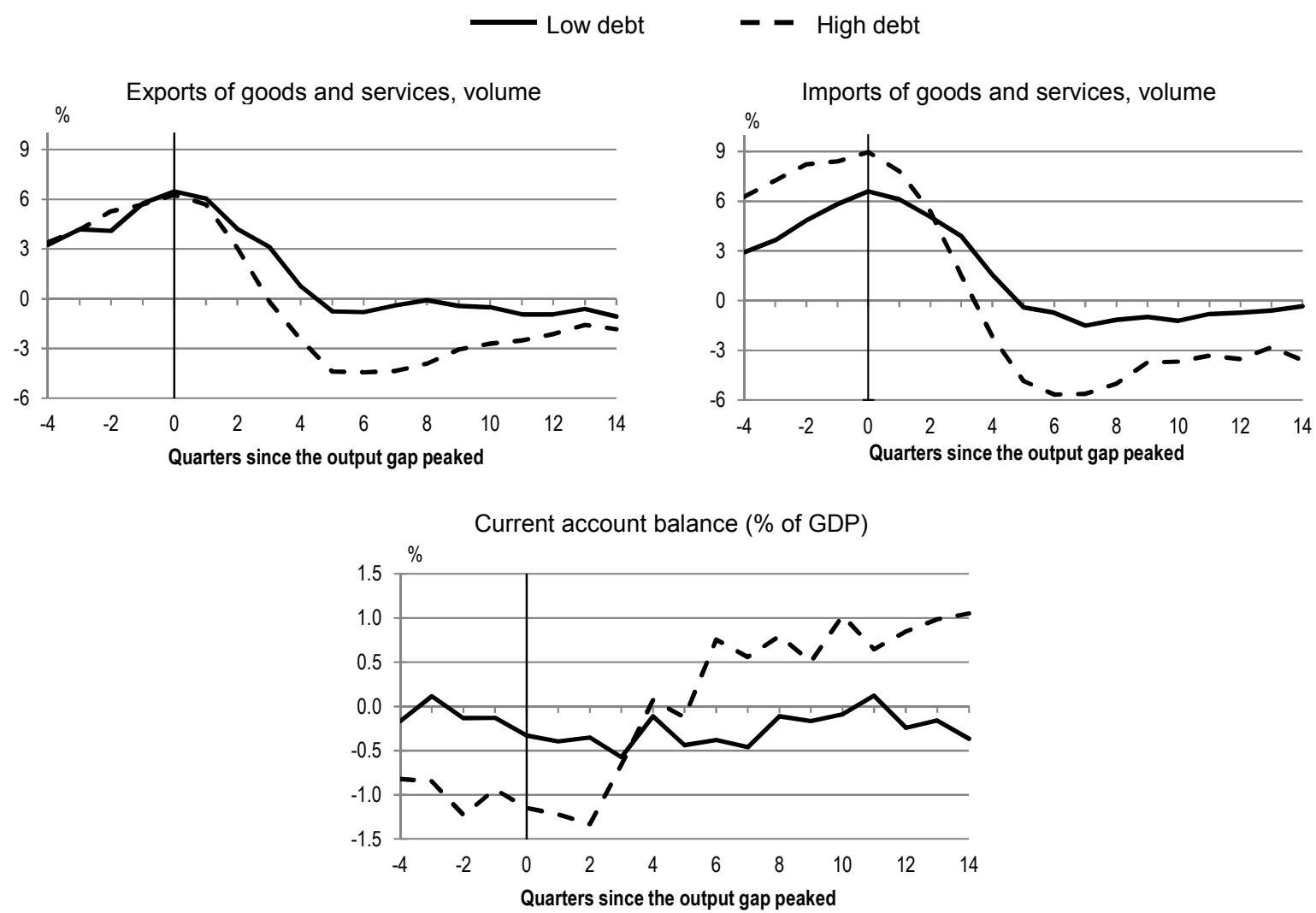

Note: The vertical line denotes the peak of the deviation business cycle. Low and high debt cycles are determined by the level of the "cyclical" component of debt to potential output at the peak of the cycle. The lines correspond to average percentage deviation paths for the corresponding variable relative to the long-term trend.

Increased government borrowing during a downturn is due to the automatic stabilisers and discretionary fiscal policy reacting to a large, adverse shock, which damps the propagation of a shock. In this context, increasing, but not high levels of government debt, are conducive to greater macroeconomic stability. However, there appear to be limits to the ability to stabilise the economy, potentially raising macroeconomic volatility. The correlation between government financial liabilities and output volatility suggests that the stabilising role of fiscal policy becomes weaker at higher levels of gross financial liabilities (Sutherland and Hoeller, 2012). The pattern suggests that there are limits to smoothing economic fluctuations, and earlier work for WP1 has identified that at high debt levels fiscal policy can become pro-cyclical (Égert, 2010).

Household debt as a share of GDP and disposable income is above trend at the peak of high-debt cycles, but relative to financial assets or net worth, it is not particularly different from trend or developments in low-debt cycles (Figure 9). However, adverse shocks to asset prices feed through quickly with financial assets dropping in value, while debt levels remain high. This explains why the measures of financial leverage rise sharply after the turning point. This highlights that households can build up vulnerabilities even when measures of financial leverage are not particularly high. 
Figure 8. Sectoral debt developments around cyclical peaks Low debt - - High debt
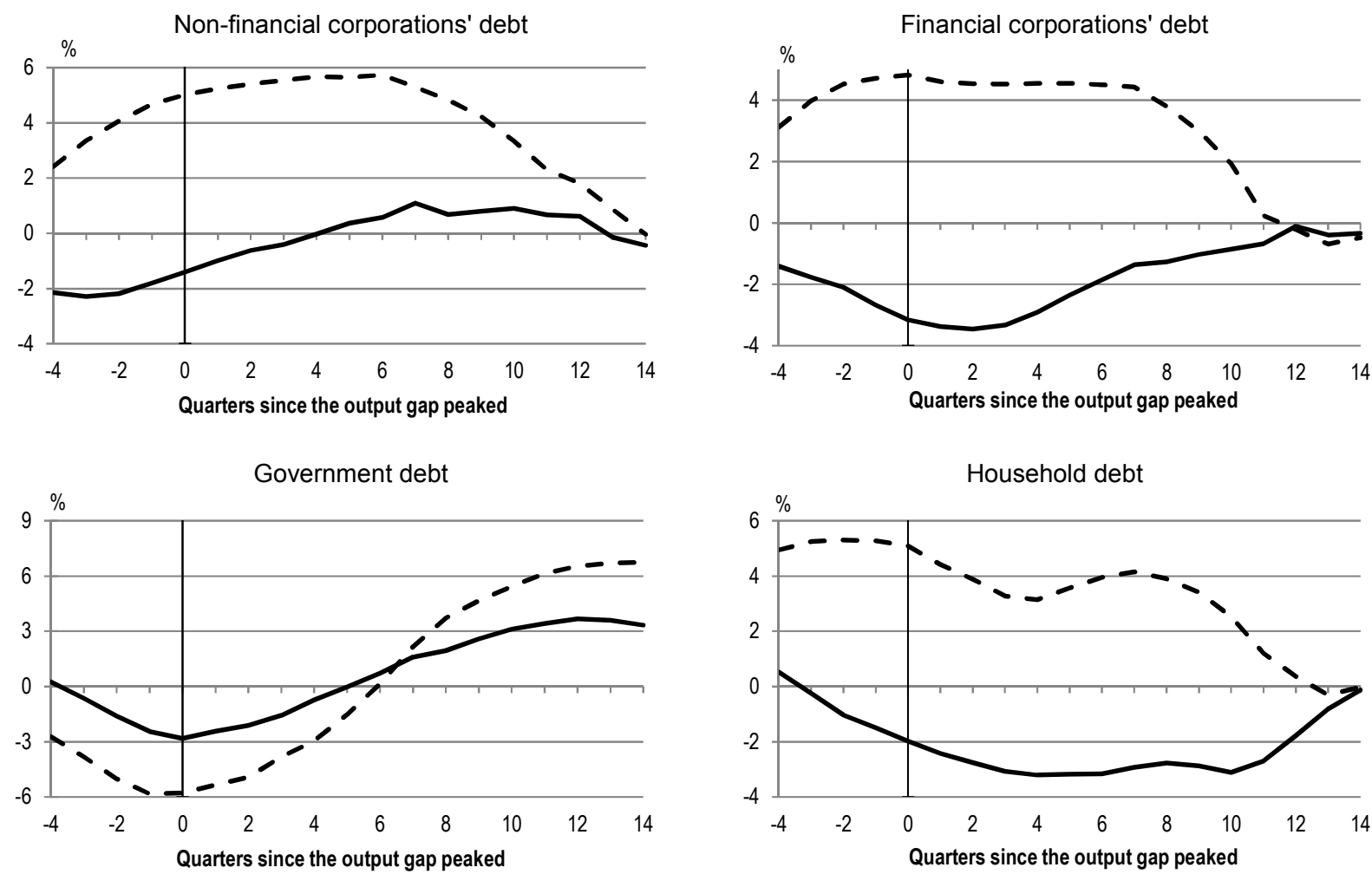

Note: The vertical line denotes the peak of the deviation business cycle. Low and high debt cycles are determined by the level of the "cyclical" component of debt to potential output at the peak of the cycle. The lines correspond to average percentage deviation paths for the corresponding variable relative to the long-term trend.

During high-debt business cycles, asset price developments have typically led to a sharp rise in asset-based leverage measures, particularly in the financial and non-financial corporate sectors. Bank lending, including inter-bank lending, can rise significantly in the run up to a turning point, boosting bank balance sheets relative to GDP (Figure 8). Before the recent crisis, growth in financial sector balance sheets was very fast and leverage measures diverge significantly in high and low-debt business cycles, especially after the peak, when asset prices fall more quickly and further than debt (Figure 10). A similar and more pronounced process occurs in the non-financial corporate sector. 
Figure 9. Measures of household debt around cyclical peaks


Note: The vertical line denotes the peak of the deviation business cycle. Low and high debt cycles are determined by the level of the "cyclical" component of debt to potential output at the peak of the cycle. The lines correspond to average percentage deviation paths for the corresponding variable relative to the long-term trend.

\section{What are the policy implications?}

The evidence above demonstrated that very costly recessions have occurred in a high-debt environment. Against this background, this section reviews some policy issues associated with the nexus between high debt and macroeconomic stability, focusing first on monetary and financial market policy, then on fiscal policy, on tax biases that push up debt in the household and business sector. These policies aim to reduce the level of debt and prevent run-ups as well as strengthening the shock absorbing capacity of the economy. The last sub-section contains a discussion of institutional arrangements for, and the possible side effects of, debt write-downs, which are likely to be the most pertinent once debt levels have reached dangerous levels. 
Figure 10. Corporate balance sheets around cyclical peaks
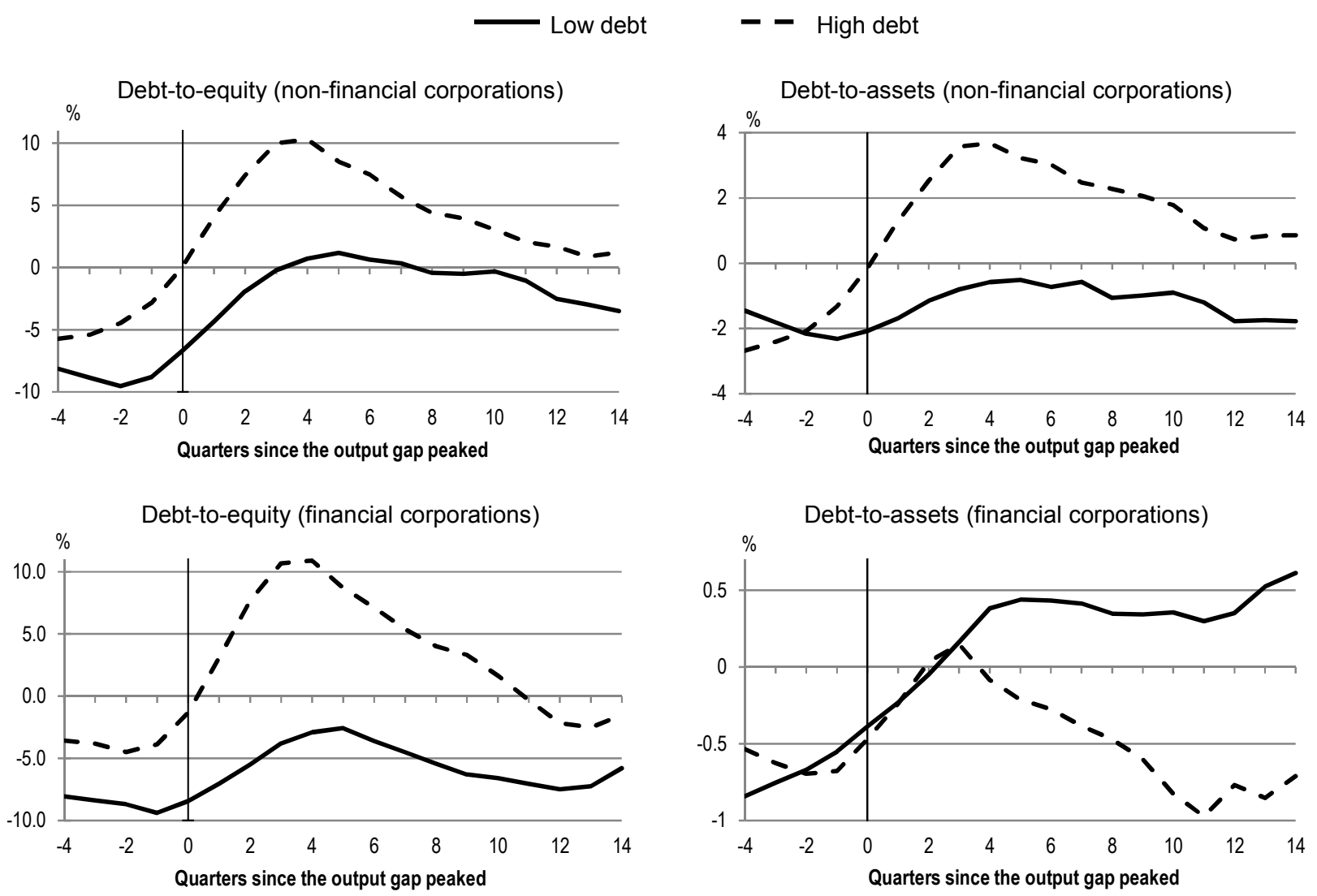

Note: The vertical line denotes the peak of the deviation business cycle. Low and high debt cycles are determined by the level of the "cyclical" component of debt to potential output at the peak of the cycle. The lines correspond to average percentage deviation paths for the corresponding variable relative to the long-term trend.

\subsection{Credit bubbles and leaning against the wind}

A challenging issue for policy is whether it should lean against the build up of debt towards high levels or clean when a recession strikes. As the costs of downturns during high-debt business cycles are generally larger than during low-debt business cycles and the recent crisis highlights just how costly they can be, the question arises as to whether and how monetary and financial market policy should react to the build up in debt. In many respects, the assessment of the available tools follows the arguments laid out in the past WP1 project on counter-cyclical economic policy (Sutherland et al., 2010), which promoted several layers of defence against credit bubbles (assuming that monetary policy is not unduly loose and directly contributing to the emergence of bubbles).

\section{Micro-prudential regulation}

Micro-prudential regulation represents the first line of defence. By enhancing the resilience of the financial sector, sound micro-prudential regulation can help damp shocks and short-circuit the transmission of debt-induced problems across sectors.

In the wake of the financial crisis a number of innovations in micro-prudential regulation are being introduced. For example, new requirements as part of the Basel III agreement are being rolled out. They mainly concern stronger capital and liquidity requirements and most importantly perhaps, a non-risk-based 
leverage ratio that includes off-balance sheet exposures that will serve as a backstop to the risk-based capital requirements. At the national level greater emphasis on more automatic responses to warning signals and the targeting of particularly vulnerable sectors should be considered. It will also be important to deal with incentive problems embedded in the structure of financial institutions and remuneration systems and to deal with moral hazard problems for systemically important financial institutions that are deemed too important to fail.

When fully implemented, the Basel III agreement should lead to benefits by reducing the frequency and severity of banking crises and the associated output losses, but will also generate costs by raising the price and availability of credit. A recent BIS (2012) paper reviews the available studies and comes to the conclusion that more stringent liquidity and capital requirements are beneficial as they lower the probability of financial crisis. On the cost side, banks are assumed to pass on the extra funding costs from more stringent regulation. ${ }^{5}$ For the net benefits, a wide range of results exists and very different results can be obtained by varying assumptions of whether financial crises result in a permanent or transitory reduction in growth.

\section{Macro-prudential policy}

Macro-prudential regulation, aims at identifying systemic threats to financial and economy-wide stability, which may be missed by micro-prudential regulation alone. It offers a second line of defence. For example, debt levels moving above trend appear to create greater vulnerabilities and risks of downturns.

The recent financial crisis exposed the lack of coordination between monetary and regulatory authorities. Adding an overarching layer of macro-prudential oversight would provide a more comprehensive view of emerging vulnerabilities, by bringing together monetary policy makers, regulators and supervisors with a shared macro-prudential focus. Macro-prudential regulations that protect against excessive credit growth are likely to reduce the risk of financial crises. In particular, macro-prudential policy should guard against credit-driven asset price bubbles getting underway or gathering too much steam. Assessing whether debt levels or credit growth is getting out of hand needs a broad examination of economic developments. Aggregate data will require supplementary analysis of whether debt burdens are tilted towards those most vulnerable to shocks. Additional areas for attention include monitoring persistent current account deficits and the extent to which capital inflows contribute to a domestic credit expansion and the extent to which gross positions are exposed to maturity and currency mismatch, liquidity and counterparty risks. Macro-prudential policy faces limitations as the measurement of systemic risks is still in its infancy. For instance, using historical data means that only vulnerabilities, types of shocks and amplification mechanisms that have been observed, will be taken into account and estimates are vulnerable to regime changes (Brunnermeier and Oehmke, 2012).

There are a number of instruments that have a strong and direct impact on credit growth and can target particularly vulnerable sectors. Credit booms are often characterised by a shift into riskier forms of lending. In this light, risk weights attached to such lending categories could be changed when setting banks' required capital, while varying margin requirements could be an appropriate instrument for dealing with vulnerabilities building up in capital markets. Other potential tools include dynamic loan loss provisioning and capital surcharges on top of prevailing micro prudential capital ratios. Tools specific to housing include capping loan-to-value ratios in mortgage lending and loan servicing costs relative to

5. A recent OECD study (Slovik and Cournède, 2012) concludes that bank lending spreads would go up by about 15 basis points, which could lead to a loss in output of about 1 1 $\frac{1}{2}$ per cent after five years. However, it also argues that if monetary policy were not constrained by the zero bound anymore, it could offset the adverse output effects by an easier monetary policy stance. 
income as well as limiting the use of exotic mortgage products. All these potential measures face practical implementation difficulties. Relevant issues include which indicators to consider when setting these policy instruments and how to calibrate the response. Another issue is whether measures should be rules based, or whether discretion should be allowed. To an important extent, the options available are more readily able to target credit growth, rather than other forms of debt.

\section{Monetary policy}

The final line of defence is monetary policy. In the absence of sufficiently robust micro and macro prudential regulation, monetary policy can influence desired debt levels by altering the price of leverage. Monetary policy can have a considerable direct effect on bank lending and other segments of financial markets via the interest rate and credit channels, as well as influencing the risk taking of banks. Low interest rates for a prolonged period boost asset prices, while reducing their volatility, which leads to lower estimated risk and encourage a search for yield. While in principle monetary policy can have a considerable effect it is a blunt tool and the dangers of misinterpreting the effects of financial innovation and mis-timing interventions could incur heavy costs. Furthermore, the changes in the monetary policy stance to rein in credit growth may need to be large, which could threaten inflation undershooting the price stability objective.

While potentially effective in leaning against a debt build-up, such a policy would also be perilous, because of the risk of error both in bursting non-bubbles and aggravating downturns by getting the timing wrong. For monetary policy to target liabilities in a reliable way, tools are needed to identify emerging credit bubbles and the timing of corrections. Schularick and Taylor (2012), for instance, use lagged credit growth on top of some controls as an indicator to forecast financial crises. While credit growth is a better predictor than money growth, there would still be a large number of false alarms of an impending financial crisis. While such estimates are useful, they do not seem to be sufficiently robust to serve as a basis for policy making. Moreover, monetary policy is a blunt tool and cannot address vulnerabilities in specific parts of the economy.

Notwithstanding the complexities involved in determining whether financial sector developments are becoming unsustainable, the costs of financial market instability on the wider economy are leading to re-evaluations of the link between monetary policy and financial stability objectives. For example, the Reserve Bank of New Zealand and the Minister of Finance concluded recently a new Policy Target Agreement, which includes an explicit reference to regarding the efficiency and soundness of the financial system whilst pursuing the price stability objective.

\subsection{Fiscal policy can provide little insurance at high debt levels}

As noted above, high government debt levels can induce fiscal policy to become pro-cyclical and thus hinder efforts to damp shocks hitting the economy. While current government debt levels partly reflect the severity of the crisis and the consequences of the difficulties experienced in the financial sector, debt levels also reflect the influence of other pressures, which have hindered many countries in brining debt levels down to prudent levels. In this context, deficit bias, leading to high debt levels has been a perennial concern. There are a number of complementary approaches to countering the deficit bias. Previous OECD work on fiscal consolidation suggested that debt targets would provide a long-term anchor for fiscal policy, which could counter the past tendency of debt levels to ratchet up during recessions (Sutherland et al., 2012). Set at a prudent level, they also provide fiscal space to cope with future shocks.

Fiscal rules represent one approach to countering the deficit bias. For example, fixing numerical targets for debt levels, budget balances, spending or taxation generates greater transparency as to when fiscal policy is off track. In this light, fiscal rules may help parliaments and populations hold the 
government accountable for fiscal policy. In the wake of the recent crisis, one unsettled question is how to design escape clauses in fiscal rules to allow fiscal policy to react to severe downturns and when the original rule should become binding again.

A fiscal council could contribute to improved fiscal performance in a number of ways (Hagemann, 2010). For example, by providing an independent view on fiscal policy, whether related to policy formulation, evaluation or monitoring, they can inform voters and other stakeholders more accurately when fiscal policy is off-track and raise the political costs of fiscal laxity. Fiscal councils can perform tasks that may mitigate specific political economy problems. When a deficit bias arises from over-optimistic forecasting an independent fiscal council given this task can eliminate that source of deficit bias. Indeed, there appears to be a relationship between comparatively poor budget outcomes and systematic over-optimism: errors in budget balance forecasts are larger for countries running worse budget positions (Frankel, 2011). ${ }^{6}$ While independent forecasting can help correct over-optimistic forecasting, deficit biases arising from other pathologies may be better addressed by other approaches such as fiscal rules.

\subsection{Taxes exert a debt bias for enterprises and households}

Tax advantages can affect the capital structure of non-financial and financial corporations as well as households, usually imparting a tax advantage to debt over equity and mortgage loan interest rate deductibility can raise household debt as well as house price volatility. Reducing these debt biases would be good for growth and potentially reduce instability. While there are good reasons to reconsider debt biases in the tax code, a reform would lower debt levels, but may be less effective in preventing recurring run-ups in debt. In principle, the tax advantage could be varied over the cycle, but this would undermine the stability of the tax system.

- Non-financial corporations: In most tax systems, interest expenses are deductible from corporate income, but equity pay-outs are not, inducing firms to have higher leverage ratios. The choice of the capital structure involves a trade-off between the benefits and costs of debt financing. Costs are related, for instance, to financial distress, while the tax advantage contributes to the benefit of debt, with the benefit rising with the marginal tax rate. The wedge between the cost of internal and external financing pushes firms towards debt (Bernanke and Gertler, 1989; Bernanke et al., 1996, 1999; Carlstrom and Fuerst, 1997).The tax advantage can be substantial. Graham (2000), for example, estimated that the subsidy to debt financing is worth almost $10 \%$ of firm value in the United States. In a meta-analysis of 46 studies, Feld et al. (2011) find that the marginal tax effect on the leverage ratio is 0.3 . The tax effects are even higher for multinational firms, reflecting additional advantages from cross-border profit shifting opportunities and intra-company debt provides another device to respond to cross-country tax differences.

- Financial corporations: Banks and other financial corporations also have an incentive to use debt, rather than equity. However, the situation is different from non-financial corporations, because regulatory requirements also drive financing decisions, though hybrid instruments (debt is held for tax and equity for regulatory purposes) complicate the analysis. In this area, there is little empirical work available. One study (Keen and de Mooij, 2012) suggests that bank capital structures are as responsive to tax asymmetries as those of non-financial firms. However, capital-constrained banks are only sensitive to changes in capital requirements, while those with large buffers show a strong response to taxation but not to capital requirements. New bank taxes

6. Cimadomo (2011) finds that numerical fiscal rules and fiscal institutions such as medium-term budgetary frameworks are associated with more accurate fiscal forecasts and data releases. 
will reduce the incentive to use debt, often being based on wholesale financing (Hagemann, 2012).

- Households: Housing demand, house prices and household leverage are also affected by taxation. Owner-occupied housing has favourable tax treatment relative to other forms of capital investment. Imputed rental income on principal homes is often not subject to income tax. Even though most countries levy property taxes, these tend to be an imperfect substitute and are low in many countries. At the same time, mortgage interest payments can be deducted from the personal income tax base in about half of the OECD countries. The tax-favouring of housing tends to encourage leverage and is capitalised into house prices (Capozza et al. 1996; Harris, 2010). Estimates by Andrews et al. (2011) suggest that in countries having more generous housing tax relief on debt financing costs, a positive demand shock translates into an increase in house prices that is around 50\% larger than in the typical OECD country. Andrews et al. (2011) also provide some evidence that mortgage interest deductibility correlates with increased real house price volatility, possibly reflecting the tendency for such policies to encourage leverage, by raising the after-tax return from engaging in speculative housing investments.

\subsection{Debt write-downs}

In light of the potential for macroeconomic instability, dealing with elevated debt levels represents a considerable challenge. In this context, procedures for writing down debt are important. Debt write-downs can hasten deleveraging and spur a more vigorous recovery from a high-debt recession and internalise social costs of disorderly bankruptcy. But they may also increase the cost of capital thereby depressing steady state growth.

For the corporate sector differences in creditor protection differ considerably across countries. Some findings point to bankruptcy codes affecting the prospects of write-downs when the debtor becomes distressed. Whether the creditor pursues firm workout, when the debt burden is renegotiated, or takes the debtor firm through bankruptcy or liquidation does not appear to depend on formal requirements to protect viable firms, but rather factors such as whether creditors are less protected residual claimants or whether creditors have created institutional structures to prevent the uncoordinated disposal of distressed assets, as in the case of British banks (Davydenko and Franks, 2008). Prompting banks to take quick action to write down distressed loans is also important to kick-start growth (Bouis, Cournède and Christensen, 2012). Past experience in the OECD suggests that failure to do so contributed to a prolonged period of sluggish growth in Japan in contrast to Sweden, where losses were recognised quickly, following the financial crisis in the early 1990s (Merola, 2012).

Write-downs are also important for households. There exist large differences across countries in this respect as well. There have been a number of reforms to personal insolvency since Denmark introduced a new system in 1984 and this approach has spread across continental Europe. The aim is to address households whose debt levels are clearly unsustainable, while maximising returns to creditors by putting reasonable claims on debtors. The process often requires the claimant to prove that there is a deserving case, before mediation sets a reasonable, but time limited, path of payments from the debtor and in return the loan can be written down (or off). Despite similarities across systems, the degree to which courts write down debt varies considerably. When it comes to write-downs in the household sector, housing loans are important as the social cost of widespread foreclosures may be substantial. In this context, a case can be made for requiring loan modifications and government subsidies. There appears to be some differences between continental Europe and the United States in this regard. In Europe, where foreclosures appear less threatening, lenders need to satisfy courts of the need to implement forced sales to recover the residual value of the property and policy interventions are aimed at preventing households being forced out of their homes. In the United States, court-based procedures also need to be followed, but foreclosures are more 
prevalent. There are also differences within the United States as loans are recourse in some states and non-recourse in others, with the latter limiting the ability of the lender to hold the debtor liable for the balance of the mortgage after foreclosure. Non-recourse loans can facilitate "jingle mail", whereby a household returns the keys to the bank and walks away from the mortgage. Indeed, default rates are higher in the states with non-recourse loans (Campbell, 2012). What is less clear is whether higher default rates are priced into interest premia, with some evidence suggesting this is not the case (Ghent and Kudlyak, 2011).

Sovereign debt write downs represent another area where macroeconomic outcomes may be improved, but can incur costs. While much of the academic literature concerns developing countries, write-downs and rescheduling of sovereign debt have gained new piquancy for OECD countries during the recent crisis. When the burden of sovereign debt overhangs force fiscal policy to become highly pro-cyclical and threaten to destabilise the economy, orderly negotiations with creditors to restructure debt could help damp macroeconomic volatility. However, there are a number of costs to debt restructuring which include:

- Higher borrowing costs and limited access to international capital markets. Empirical evidence suggests that countries have been punished only in the immediate aftermath of a debt restructuring. However, more recent evidence reviewed by Das et al. (2012) suggests that when the write down (haircut) is large, borrowing costs rise and remain elevated by around 50 basis points for at least six years. Furthermore, regaining access to international capital markets is more difficult when the debt write down is large.

- Drying up of foreign financing. In the wake of a sovereign debt restructuring, private sector external borrowing is depressed and can fall substantially. Furthermore, foreign direct investment can fall by $2 \%$ of GDP

- Difficulties for the domestic financial sector. Particularly for domestic bonds, debt write downs can have important effects on banks, insurance companies, pension funds and other financial intermediaries, both through the direct effect on balance sheets, but also through limited access to external financing, which can dry up during debt restructuring negotiations.

- Costs associated with restructuring negotiations can be substantial. Fees and legal costs can amount to significant amounts during restructuring. According to Das et al. (2012) fees have accounted for $2 \%$ of the restructured volumes. 


\section{REFERENCES}

Ahrend, R. and A. Goujard (2011), "Drivers of Systemic Banking Crises: the Role of Bank-balance-sheet Contagion and Financial Account Structure", OECD Economics Department Working Papers, No. 902, OECD Publishing.

Aizenman, J., B. Pinto and V. Sushko (2011), "Financial Sector Ups and Downs and the Real Sector: Big Hindrance, Little Help", NBER Working Paper, No. 17530.

Allen, M., C. Rosenberg, C. Keller, B. Setser and N. Roubini (2002), “A Balance Sheet Approach to the Financial Crisis", IMF Working Paper, No. WP/02/210.

Andrews, A., A. Caldera Sánchez and Å. Johansson (2011), "Housing Markets and Structural Policies in OECD Countries", OECD Economics Department Working Papers, No. 836, OECD Publishing.

Banerjee, A. and M. Marcellino (2006), "Are there Any Reliable Leading Indicators for US Inflation and Growth?”, International Journal of Forecasting, Vol. 22, pp. 137-151.

Barrell, R., E. Davis and O. Pomerantz (2006), "Costs of Financial Instability, Household-sector Balance Sheets and Consumption”, Journal of Financial Stability, Vol. 2, pp. 194-216.

Bernanke, B. and M. Gertler (1989), "Agency Costs, Net Worth and Business Fluctuations", American Economic Review, Vol. 79.

Bernanke, B. and M. Gertler (1990), "Financial Fragility and Economic Performance", Quarterly Journal of Economics, Vol. 105.

Bernanke, B., M. Gertler and S. Gilchrist (1996), "The Financial Accelerator and the Flight to Quality", Review of Economics and Statistics, Vol. 78.

Bernanke, B., M. Gertler and S. Gilchrist (1999), "The Financial Accelerator in a Quantitative Business Cycle Framework", in J. Taylor and M. Woodford (eds), Handbook of Macroeconomics, pp. 1341-1393.

BIS (2012), "The Policy Implications of Transmission Channels between the Financial System and the Real Economy", Basel Committee on Banking Supervision Working Paper, No. 20.

Blanchard, O. and J. Simon (2001), "The Long and Large Decline in U.S. Output Volatility", Brookings Papers on Economic Activity, No. 1.

Bouis, R., B. Cournède and A. Christensen (2012), "Deleveraging: Challenges, Progress and Policies", OECD Economics Department Working Papers, No. 999, OECD Publishing.

Brunnermeier, M. and M. Oehmke (2012), "Bubbles, Financial Crises, and Systemic Risk", NBER Working Paper, No. 18398.

Campbell, J. (2012), “Mortgage Market Design”, NBER Working Paper, No. 18339. 
Caner, M., T. Grennes and F. Koehler-Geib (2010), "Finding the Tipping Point - When Sovereign Debt Turns Bad”, World Bank Policy Research Working Paper, No. 5391.

Canova, F. (2007), Methods for Applied Macroeconomic Research, Princeton University Press.

Capozza, D., R. Green and P. Hendershott (1996), “Taxes, Mortgage Borrowing, and Residential Land Prices", in H.J. Aaron and W.G. Gale (eds.), Economic Effects of Fundamental Tax Reform, Brookings Institution Press, Washington, pp. 171-198.

Carlstrom, C. and T. Fuerst (1997), "Agency Costs, Net Worth, and Business Fluctuations: A Computable General Equilibrium Analysis", American Economic Review, Vol. 87.

Cecchetti, S., M. Mohanty and F. Zampolli (2011), "The Real Effects of Debt", BIS Working Paper, No. 352.

Cetorelli, N. and L. Goldberg (2012), "Banking Globalization and Monetary Transmission”, Journal of Finance, Vol. 67.

Checherita, C. and P. Rother (2010), "The Impact of High and Growing Government Debt on Economic Growth. An Empirical Investigation for the Euro Area", ECB Working Paper, No. 1237.

Cimadomo, J. (2011), "Real-time Data and Fiscal Policy Analysis: A Survey of the Literature", Federal Reserve Bank of Philadelphia Research Department Working Paper, No. 11-25.

Corsetti, G., K. Kuester, A. Meier and G. Müller (2011), "Sovereign Risk and Macroeconomic Stability”, Mimeo.

Das, U., M. Papaioannou and C. Trebesch (2012), "Sovereign Debt Restructurings 1950-2010: Concepts, Literature Survey, and Stylized Facts", IMF Working Papers, No. WP/12/203.

Davis, E. (2010), “Asset Prices and Real Economic Activity", OECD Economics Department Working Papers, No. 764, OECD Publishing.

Davis, E. and M. Stone (2004), "Corporate Financial Structure and Financial Stability”, Journal of Financial Stability, Vol 1.

Davydenko, S. and J. Franks (2008), "Do Bankruptcy Codes Matter? A Study of Defaults in France, Germany and the U.K.", Journal of Finance, Vol. 63, pp. 565-608.

DeLong, B. and L. Summers (2012), "Fiscal Policy in a Depressed Economy", Mimeo.

Diaz-Alejandro, C. (1985), “Good-bye Financial Repression, Hello Financial Crash”, Journal of Development Economics", Vol. 19, pp. 1-24.

Égert, B. (2010), "Fiscal Policy Reaction to the Cycle in the OECD", OECD Economics Department Working Papers, No. 763, OECD Publishing.

Égert, B. (2012), “Public Debt, Economic Growth and Nonlinear Effects: Myth or Reality?”, No. 993, OECD Publishing.

Estrella, A., A. Rodrigues and S. Schich (2003), "How Stable Is the Predictive Power of the Yield Curve? Evidence from Germany and the United States", Review of Economics and Statistics, Vol. 85, No. 3, pp. 629-644. 
Feld, L.P. et al. (2011), "Capital Structure Choice and Company Taxation: A Meta-Study", CESIFO Working Paper, No. 3400.

Frenkel, J. (2011), “Over-optimism in Forecasts by Official Agencies and its Implications”, Oxford Review of Economic Policy, Vol. 27.

Ghent, A. and M. Kudlyak, 2011), "Recourse and Residential Mortgage Default: Evidence from U.S. States", Federal Reserve Bank of Richmond Working Paper, No. 09-10R.

Giannetti, M. and L. Laeven (2012), "Flight Home, Flight Abroad, and International Credit Cycles", American Economic Review: Papers \& Proceedings, Vol. 102, No. 3, pp. 219-224.

Graham, J. (2000), “How Big are the Tax Benefits of Debt?”, Journal of Finance, Vol. 55.

Hagemann, R. (2010), "Improving Fiscal Performance through Fiscal Councils", OECD Economics Department Working Papers, No. 829.

Hagemann, R. (2012), "Fiscal Consolidation: Part 6. What Are the Best Policy Instruments for Fiscal Consolidation?", OECD Economics Department Working Papers, No. 937, OECD Publishing.

Harris, B. (2010), "The Effect of Proposed Tax Reforms on Metropolitan Housing Prices", Tax Policy Center Working Paper, April.

Jimenéz, G., S. Ongena, J-L. Peydró and J. Saurina (2012), “Credit Supply Versus Demand: Bank and Firm Balance-sheet Channels in Good and Crisis Times", Tilberg University, European Banking Center Discussion Paper, No. 2012-003.

Jorda, O., M. Schularick and A. Talyor (2011), "When Credit Bites Back: Leverage, Business Cycles, and Crises", Federal Reserve Bank of San Francisco Working Paper, No. 2011-27.

Keen, M. and R. de Mooij (2012), “Debt, Taxes, and Banks”, IMF Working Paper, No. WP/12/48.

Kiyotaki, N. and J. Moore (1997), “Credit Cycles”, Journal of Political Economy, Vol. 105.

Korinek, A. (2011), "Foreign Currency Debt, Risk Premia and Macroeconomic Volatility", European Economic Review, Vol. 55.

Kumar, M.S. and J. Woo (2010), "Public Debt and Growth”, IMF Working Paper, WP/10/174.

Laubach, T. (2003), "New Evidence on the Interest Rate Effects of Budget Deficits and Debt", Journal of the European Economic Association, Vol. 7.

Mendoza, E. and K. Smith (2006), "Quantitative Implications of Debt-deflation Theory of Sudden Stops and Asset Prices", Journal of International Economics, Vol. 70, pp. 82-114.

Merola, R. (2012), "Debt and Macroeconomic Stability: Case Studies", OECD Economics Department Working Papers, No. 1004, OECD Publishing.

Mullineux, A., V. Murinde and R. Sensarma (2011), "Corporate Financing and Macroeconomic Volatility in the European Union", International Economics and Economic Policy, Vol. 8.

Obstfeld, M. (2012), "Does the Current Account Still Matter?”, American Economic Review: Papers \& Proceedings, Vol. 102, No. 3, pp. 1-23. 
Reinhart, C.M. and K.S. Rogoff (2010), "Growth in a Time of Debt", American Economic Review, Vol. 100, No. 2.

Röhn, O. (2010), "New Evidence on the Private Saving Offset and Ricardian Equivalence", OECD Economics Department Working Papers, No. 762, OECD Publishing.

Rousová, L. and P. van den Noord (2011), "Predicting Peaks and Troughs in Real House Prices", OECD Economics Department Working Papers, No. 882, OECD Publishing.

Rudebusch, G. and J. Williams (2012), "Forecasting Recessions: The Puzzle of the Enduring Power of the Yield Curve", Journal of Business and Economic Statistics, Vol. 27, No. 4, pp. 492-503.

Schularick, M. and A. Taylor (2012), "Credit Booms Gone Bust: Monetary Policy, Leverage Cycles, and Financial Crises, 1870-2008”, American Economic Review, Vol. 102.

Slovik, P. and B. Cournède (2012), "Macroeconomic Impact of Basel III", OECD Economics Department Working Papers, No. 844, OECD Publishing.

Stock, J. and M. Watson (2001), "Forecasting Output and Inflation: The Role of Asset Prices", NBER Working Paper, No. 8180.

Sutherland, A. (1997), "Fiscal Crises and Aggregate Demand: Can High Public Debt Reverse the Effects of Fiscal Policy?", Journal of Public Economics, Vol. 65, pp. 147-162.

Sutherland, D. and P. Hoeller (2012), "Debt and Macroeconomic Stability: An Overview of the Literature with some Empirics", OECD Economics Department Working Papers, No. 1006, OECD Publishing.

Sutherland, D., P. Hoeller and R. Merola (2012), "Fiscal Consolidation Part 1: How Much is Needed and How to Reduce Debt to a Prudent Level", OECD Economics Department Working Papers, No. 932, OECD Publishing.

Sutherland, D., P. Hoeller, B. Égert and O. Röhn (2010), "Counter-cyclical Economic Policy”, OECD Economics Department Working Papers, No. 760, OECD Publishing.

Tressel, T. (2010), "Financial Contagion through Bank Deleveraging: Stylized Facts and Simulations Applied to the Financial Crisis", IMF Working Paper, No. WP/10/236.

Turner, D. and F. Spinelli (2011), "Explaining the Interest-Rate-Growth Differential Underlying Government Debt Dynamics", OECD Economics Department Working Papers, No. 919, OECD Publishing.

Wheelock, D. and M. Wohar (2009), "Can the Term Spread Predict Output Growth and Recessions? A Survey of the Literature", Federal Reserve Bank of St. Louis Review, September/October Part 1, pp. 419-440.

Yang, J. and K. Tsatsaronis (2012), "Bank Stock Returns, Leverage and the Business Cycle", BIS Quarterly Review, March.

Ziemann, V. (2012), "Debt and Macroeconomic Stability: Debt and the Business Cycle", OECD Economics Department Working Papers, No. 1005, OECD Publishing. 
APPENDIX

Table AP.1. Debt and leverage

2009/10 (latest available year)

\begin{tabular}{|c|c|c|c|c|c|c|c|c|c|c|c|}
\hline & \multicolumn{4}{|c|}{ Gross debt, $\%$ of GDP } & \multicolumn{4}{|c|}{ Net financial wealth, $\%$ of GDP } & \multicolumn{3}{|c|}{ Leverage ratio } \\
\hline & $\begin{array}{c}\text { Non- } \\
\text { financial }\end{array}$ & Financial & Government & Households & $\begin{array}{c}\text { Non- } \\
\text { financial }\end{array}$ & Financial & Government & Households & Non-Financial & Financial & Households \\
\hline \multicolumn{12}{|l|}{ AUS } \\
\hline AUT & 117 & 378 & 88 & 57 & -91 & 6 & -44 & 120 & 0.94 & 5.01 & 0.94 \\
\hline BEL & 181 & 435 & 114 & 55 & -102 & -2 & -80 & 204 & 0.56 & 7.58 & 0.89 \\
\hline CAN & 105 & & 113 & 94 & -127 & -9 & -49 & 174 & & 3.87 & 1.49 \\
\hline $\mathrm{CHE}$ & 99 & & & 124 & & & & 232 & & 3.70 & 2.04 \\
\hline $\mathrm{CHL}$ & 135 & 187 & 17 & 34 & -109 & 5 & 1 & 99 & 0.81 & 8.15 & 0.63 \\
\hline CZE & 106 & 148 & 45 & 34 & -95 & -3 & -2 & 63 & 0.97 & 8.33 & 0.63 \\
\hline DEU & 112 & & 88 & 62 & -59 & 4 & -50 & 126 & 1.50 & 7.45 & 1.00 \\
\hline DNK & 117 & 575 & 64 & 151 & -95 & 1 & 2 & 102 & 0.83 & 7.01 & 3.56 \\
\hline ESP & 198 & 396 & 77 & 91 & -136 & 13 & -41 & 78 & 1.36 & 9.64 & 1.40 \\
\hline EST & 181 & 155 & 14 & & & 5 & 37 & & 0.98 & 6.35 & 1.24 \\
\hline FIN & 145 & 245 & 62 & 68 & -128 & 4 & 65 & 66 & 1.00 & 5.31 & 1.18 \\
\hline FRA & 152 & 444 & 105 & 65 & -113 & 18 & -59 & 142 & 0.73 & 5.55 & 0.97 \\
\hline GBR & 133 & 853 & 89 & 106 & -123 & -25 & -56 & 191 & 0.91 & 12.42 & 1.71 \\
\hline GRC & 76 & 270 & 133 & 66 & -66 & 1 & -91 & 56 & 1.92 & 10.62 & 0.80 \\
\hline HUN & 180 & 178 & 87 & 42 & -121 & 5 & -61 & 67 & 0.75 & 7.28 & 0.75 \\
\hline IRL & 283 & 1543 & 96 & 124 & -124 & -2 & -50 & 75 & 1.48 & 3.67 & 2.33 \\
\hline ISL & & & 127 & & & & -48 & & & & \\
\hline ISR & & 315 & 108 & 55 & -139 & -3 & -53 & 206 & & & \\
\hline ITA & 125 & 284 & 129 & 59 & -127 & 26 & -99 & 175 & 1.22 & 10.24 & 0.90 \\
\hline JPN & 165 & 538 & 215 & 79 & -78 & 1 & -110 & 242 & 1.73 & 13.22 & 1.35 \\
\hline KOR & 169 & 364 & 35 & 85 & -152 & 0 & 37 & 101 & 1.38 & 14.92 & 1.53 \\
\hline LUX & 332 & 3776 & 27 & 52 & -253 & 337 & 50 & 82 & 0.36 & 1.58 & 1.43 \\
\hline MEX & 12 & & & & & & & & 0.32 & 3.62 & \\
\hline NLD & 125 & 822 & 78 & 133 & -56 & 1 & -34 & 166 & 0.97 & 4.03 & 2.91 \\
\hline NOR & 171 & 260 & 65 & 93 & -90 & 8 & 164 & 13 & & 9.34 & 2.08 \\
\hline \multicolumn{12}{|l|}{ NZL } \\
\hline POL & 78 & 121 & 66 & 36 & -80 & -4 & -30 & 49 & 0.98 & 5.34 & 0.53 \\
\hline PRT & 217 & 413 & 108 & 106 & -164 & -1 & -62 & 123 & 1.12 & 5.37 & 1.60 \\
\hline SVK & 87 & 132 & 51 & 49 & -42 & 4 & -25 & 14 & 1.85 & 10.45 & 0.78 \\
\hline SVN & 145 & 183 & 58 & 35 & -117 & 4 & -7 & 83 & 1.41 & 7.70 & 0.55 \\
\hline SWE & 195 & 354 & 52 & 86 & -173 & 12 & 26 & 113 & 0.79 & 5.29 & 1.67 \\
\hline TUR & & 89 & & & & -8 & & & & & \\
\hline USA & 119 & 318 & 102 & 96 & -156 & -3 & -73 & 243 & 0.79 & 3.65 & 1.30 \\
\hline
\end{tabular}

Note: The leverage ratio for the non-financial corporate sector is defined as financial liabilities other than equity and derivatives over equity, for the financial sector it is financial assets over equity and for the household sector it is financial liabilities over disposable income.

Source: OECD, National Accounts, OECD Economic Outlook 91 database. 
Table AP.2. Characteristics of real GDP, consumption and investment cycles when debt is high and low Earliest available year to 2010

\begin{tabular}{|c|c|c|c|c|c|c|c|c|c|c|c|c|c|c|c|}
\hline & \multicolumn{5}{|c|}{ GDP } & \multicolumn{5}{|c|}{ Consumption } & \multicolumn{5}{|c|}{ Investment } \\
\hline & \multirow{2}{*}{$\begin{array}{l}\text { Number of } \\
\text { recessions }\end{array}$} & \multicolumn{2}{|c|}{ Contraction } & \multicolumn{2}{|c|}{$\begin{array}{l}\text { Previous } \\
\text { expansion }\end{array}$} & \multirow{2}{*}{$\begin{array}{l}\text { Number of } \\
\text { recessions }\end{array}$} & \multicolumn{2}{|c|}{ Contraction } & \multicolumn{2}{|c|}{$\begin{array}{l}\text { Previous } \\
\text { expansion }\end{array}$} & \multirow{2}{*}{$\begin{array}{l}\text { Number of } \\
\text { recessions }\end{array}$} & \multicolumn{2}{|c|}{ Contraction } & \multicolumn{2}{|c|}{$\begin{array}{l}\text { Previous } \\
\text { expansion }\end{array}$} \\
\hline & & Size & Length & Size & Length & & Size & Length & Size & Length & & Size & Length & Size & Length \\
\hline \multicolumn{16}{|c|}{ Total economy } \\
\hline High & 45 & -4 & 4 & 26 & 29 & 47 & -3 & 4 & 27 & 30 & 78 & -10 & 5 & 24 & 12 \\
\hline Low & 25 & -2 & 4 & 16 & 20 & 22 & -2 & 4 & 21 & 27 & 52 & -4 & 3 & 15 & 10 \\
\hline \multicolumn{16}{|c|}{ Household } \\
\hline High & 42 & -4 & 4 & 28 & 31 & 44 & -3 & 4 & 31 & 34 & 79 & -9 & 5 & 21 & 12 \\
\hline Low & 32 & -2 & 3 & 15 & 18 & 29 & -2 & 3 & 13 & 18 & 57 & -6 & 4 & 20 & 11 \\
\hline \multicolumn{16}{|c|}{ Government } \\
\hline High & 27 & -2 & 3 & 18 & 23 & 28 & -2 & 4 & 14 & 16 & 57 & -6 & 4 & 18 & 10 \\
\hline Low & 48 & -4 & 4 & 25 & 27 & 46 & -4 & 4 & 32 & 35 & 79 & -10 & 5 & 24 & 13 \\
\hline \multicolumn{16}{|c|}{ Financial } \\
\hline High & 41 & -5 & 4 & 27 & 30 & 46 & -3 & 4 & 25 & 29 & 76 & -10 & 5 & 24 & 13 \\
\hline Low & 33 & -2 & 4 & 16 & 19 & 26 & -3 & 4 & 25 & 27 & 57 & -7 & 4 & 18 & 10 \\
\hline \multicolumn{16}{|c|}{ Non-financial } \\
\hline High & 46 & -4 & 4 & 25 & 28 & 44 & -3 & 4 & 29 & 32 & 76 & -10 & 5 & 22 & 12 \\
\hline Low & 21 & -3 & 4 & 19 & 23 & 24 & -2 & 4 & 17 & 21 & 48 & -5 & 3 & 19 & 11 \\
\hline
\end{tabular}


ECO/WKP(2012)80

\section{WORKING PAPERS}

The full series of Economics Department Working Papers can be consulted at www.oecd.org/eco/workingpapers/

1002. Reducing greenhouse gas emissions in a cost effective way in Switzerland.

(December 2012) by Anita Wölfl and Patrizio Sicari

1001. Strengthening innovation in the United States

(November 2012) by David Carey, Christopher Hill and Brian Kahin

1000. Long-term growth scenarios

(forthcoming) by Åsa Johansson, Yvan Guillemette, Fabrice Murtin, David Turner,

Giuseppe Nicoletti, Christine de la Maisonneuve, Philip Bagnoli, Guillaume Bousquet and

Francesca Spinelli

999. Selected aspects of household savings in Germany-evidence from micro-data

(November 2012) by Christina Kolerus, Isabell Koske and Felix Hüfner

998. Improving the tax system in Indonesia

(November 2012) by Jens Arnold

997. Unleashing business innovation in Canada

(November 2012) by Alexandra Bibbee

996. Public policy and resource allocation: evidence from firms in OECD countries

(October 2012) by Dan Andrews and Federico Cingano

995. Promoting SME development in Indonesia

(October 2012) by Annabelle Mourougane

994. Portugal: Rebalancing the economy and returning to growth through job creation and better capital allocation.

(October 2012) by Álvaro Pina and Ildeberta Abreu

993. Public debt, economic growth and nonlinear effects: Myth or reality?

(October 2012) by Balázs Égert

992. Choosing the pace of fiscal consolidation

(September 2012) by Lukasz Rawdanowicz

991. Tertiary education developing skills for innovation and long-term growth in Canada (September 2012) by Calista Cheung, Yvan Guillemette and Shahrzad Mobasher-Fard

990. Trade and product market policies in upstream sectors and productivity in downstream sectors: firm-level evidence from China

(September 2012) by Maria Bas and Orsetta Causa

989. Intangible assets, resource allocation and growth: a framework for analysis (September 2012) by Dan Andrews and Alain de Serres 
988. Current account benchmarks for Turkey

(September 2012) by Oliver Röhn

987. Structural reforms to boost Turkey's long-term growth

(September 2012) by Rauf Gönenç, Oliver Röhn, Vincent Koen and Şeref Saygili

986. Tackling Turkey's external and domestic macroeconomic imbalances

(September 2012) by Oliver Röhn, Rauf Gönenç, Vincent Koen and Ramazan Karaşahin

985. Portugal: Solid foundations for a sustainable fiscal consolidation

(September 2012) by David Haugh and Stéphane Sorbe

984. Portugal: Assessing the risks around the speed of fiscal consolidation in an uncertain environment

(September 2012) by Stéphane Sorbe

983. The German labour market: preparing for the future

(September 2012) by Felix Hüfner and Caroline Klein

982. Climate change policies in Germany: make ambition pay

(September 2012) by Caroline Klein

981. Restarting the growth engine in Finland

(September 2012) by Henrik Braconier

980. Import Competition, Domestic Regulation and Firm-Level Productivity Growth in the OECD (September 2012) by Sarra Ben Yahmed and Sean Dougherty

979. Non-Parametric Stochastic Simulations to Investigate Uncertainty around the OECD Indicator Model Forecasts

(August 2012) by Elena Rusticelli

978. Measuring GDP Forecast Uncertainty using Quantile Regressions (July 2012) by Thomas Laurent and Tomasz Kozluk

977. Implications of output gap uncertainty in times of crisis

(July 2012) by Romain Bouis, Boris Cournède and Ane Kathrine Christensen

976. Avoiding debt traps: financial backstops and structural reforms

(July 2012) by Pier Carlo Padoan, Urban Sila and Paul van den Noord

975. Sluggish productivity growth in Denmark: the usual suspects?

(July 2012) by Müge Adalet McGowan and Stéphanie Jamet

974. Towards green growth in Denmark: improving energy and climate change policies (July 2012) by Stéphanie Jamet

973. An Analysis of Productivity Performance in Spain before and during the Crisis: Exploring the Role of Institutions

(June 2012) Juan S. Mora-Sanguinetti and Andrés Fuentes 